\title{
Presynaptic LTP and LTD of Excitatory and Inhibitory Synapses
}

\author{
Pablo E. Castillo \\ Dominick P. Purpura Department of Neuroscience Albert Einstein College of Medicine, Bronx, New York 10461 \\ Correspondence: pablo.castillo@einstein.yu.edu
}

Ubiquitous forms of long-term potentiation (LTP) and depression (LTD) are caused by enduring increases or decreases in neurotransmitter release. Such forms or presynaptic plasticity are equally observed at excitatory and inhibitory synapses and the list of locations expressing presynaptic LTP and LTD continues to grow. In addition to the mechanistically distinct forms of postsynaptic plasticity, presynaptic plasticity offers a powerful means to modify neural circuits. A wide range of induction mechanisms has been identified, some of which occur entirely in the presynaptic terminal, whereas others require retrograde signaling from the postsynaptic to presynaptic terminals. In spite of this diversity of induction mechanisms, some common induction rules can be identified across synapses. Although the precise molecular mechanism underlying long-term changes in transmitter release in most cases remains unclear, increasing evidence indicates that presynaptic LTP and LTD can occur in vivo and likely mediate some forms of learning.

\begin{abstract}
$A^{t}$ several excitatory and inhibitory synapAses, neuronal activity can trigger enduring increases or decreases in neurotransmitter release, thereby producing long-term potentiation (LTP) or long-term depression (LTD) of synaptic strength, respectively. In the last decade, many studies have revealed that these forms of plasticity are ubiquitously expressed in the mammalian brain, and accumulating evidence indicates that they may underlie behavioral adaptations occurring in vivo. These studies have also uncovered a wide range of induction mechanisms, which converge on the presynaptic terminal where an enduring modification in the neurotransmitter release process takes place. Interestingly, presynaptic forms of LTP/ LTD can coexist with classical forms of post-
\end{abstract}

synaptic plasticity. Such diversity expands the dynamic range and repertoire by which neurons modify their synaptic connections. This review discusses mechanistic aspects of presynaptic LTP and LTD at both excitatory and inhibitory synapses in the mammalian brain, with an emphasis on recent findings.

\section{INDUCTION MECHANISMS}

As illustrated in Figure 1, presynaptic LTP/LTD at both excitatory and inhibitory synapses can be induced in a homosynaptic or heterosynaptic manner, with induction occurring either entirely at the presynaptic terminal or requiring a retrograde messenger arising from the postsynaptic neuron. Each of these four induction

Editors: Morgan Sheng, Bernardo Sabatini, and Thomas Südhof

Additional Perspectives on The Synapse available at www.cshperspectives.org

Copyright (C) 2012 Cold Spring Harbor Laboratory Press; all rights reserved; doi: 10.1101/cshperspect.a005728

Cite this article as Cold Spring Harb Perspect Biol 2012;4:a005728 
P.E. Castillo
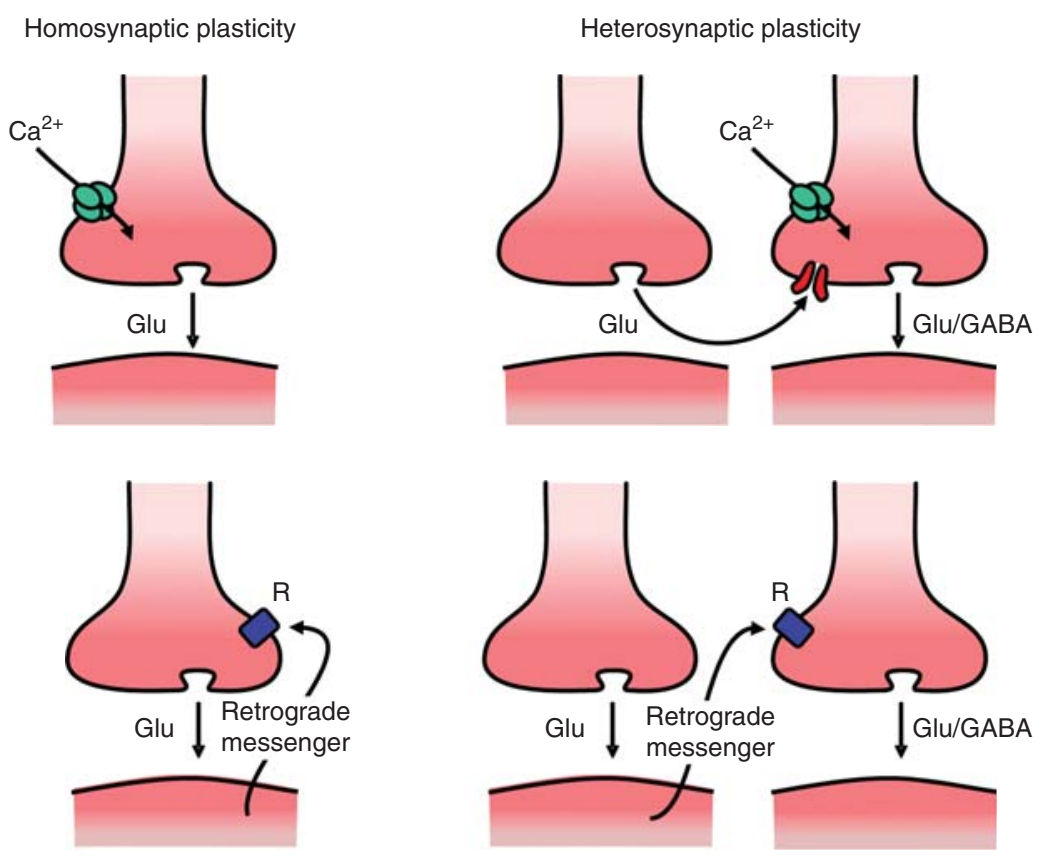

Figure 1. Four basic arrangements for presynaptic LTP and LTD. (Top row) Illustrates examples where plasticity is entirely induced presynaptically, either in a homosynaptically (e.g., mossy fiber LTP) or heterosynaptically (e.g., associative cortico-lateral amygdala LTP of glutamatergic transmission). (Bottom row) Examples requiring retrograde signaling generated either at the same synapse receiving the signal (left, e.g., eCB-LTD at excitatory synapses) or at a neighboring synapse (right, e.g., eCB-LTD at inhibitory synapses).

mechanisms will be discussed and is summarized in Table 1.

\section{Mossy Fiber to CA3 Pyramidal Cell Synapse as a Model for Presynaptic LTP/LTD}

Arguably, the best characterized form of presynaptic LTP can be found at the mossy fiber (MF) synapse between dentate gyrus granule cells and hippocampal CA3 pyramidal (Nicoll and Schmitz 2005). MF-LTP is a prototype for mechanistically similar, presynaptically expressed, NMDAR-independent and cAMP/ PKA-dependent forms of LTP found in several brain areas including the cerebellum ( $\mathrm{Sa}$ lin et al. 1996a), thalamus (Castro-Alamancos and Calcagnotto 1999), subiculum (Behr et al. 2009), amygdala (Lopez de Armentia and Sah 2007), and neocortex (Chen et al. 2009). MFLTP is mechanistically distinct from classical NMDAR-dependent LTP at the Schaffer collat- eral to CA1 pyramidal cell synapse (Sch-CA1) (Nicoll and Malenka 1995). Repetitive activation of MFs with high frequency stimulation (HFS, typically $100 \mathrm{~Hz}$ bursts), or naturally occurring activity patterns (Gundlfinger et al. 2010; Mistry et al. 2010), triggers a long-lasting increase in presynaptic release probability $(\mathrm{Pr})$ and a potentiation of the excitatory synaptic response (Nicoll and Schmitz 2005).

Strong evidence indicates MF-LTP results from enhanced glutamate release, including changes in paired-pulse facilitation, failure rate, coefficient of variation, miniature EPSC activity, and MK-801 sensitivity (Nicoll and Schmitz 2005). Unlike Sch-CA1 LTP induction, classical presynaptic MF-LTP is NMDAR-independent (Harris and Cotman 1986). Evidence indicates that LTP is induced by an activity-dependent increase in $\mathrm{Ca}^{2+}$ concentration within MF terminals (Zalutsky and Nicoll 1990; Mellor and Nicoll 2001) (but see Yeckel et al. 1999). Although 


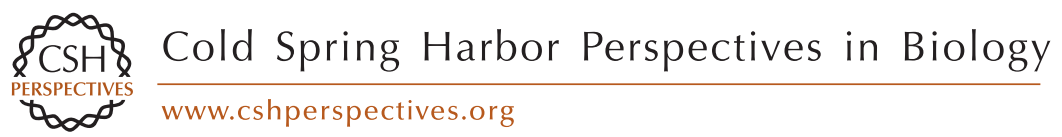

Table 1. Presynaptic long-term plasticity at excitatory and inhibitory synapses in the mammalian brain

\begin{tabular}{|c|c|c|c|c|c|}
\hline $\begin{array}{l}\text { Brain area } \\
\text { (species) }\end{array}$ & LTP/LTD & Synapse type & Induction protocol $^{\mathrm{a}}$ & Induction requirements & References $^{\mathrm{b}}$ \\
\hline Visual cortex (rat) & LTD & $\begin{array}{l}\text { Excitatory inputs, L5 } \\
\text { pyramidal cell pairs }\end{array}$ & STDP pairing protocol & $\begin{array}{l}\text { eCB signaling; postsynaptic } \\
\mathrm{Ca}^{2+} ; \text { presynaptic NMDAR }\end{array}$ & $\begin{array}{l}\text { Sjöstrom et al. 2003; Corlew et al. } \\
2007\end{array}$ \\
\hline $\begin{array}{l}\text { Immature visual } \\
\text { cortex (mouse) }\end{array}$ & LTD & $\begin{array}{l}\text { Excitatory inputs L4 to } \\
\text { L2/3 neurons }\end{array}$ & TBS & eCB signaling; mGluR5 & Huang et al. 2008 \\
\hline $\begin{array}{l}\text { Visual cortex } \\
\quad(\text { mouse, rat })\end{array}$ & LTD & $\begin{array}{l}\text { GABAergic inputs to } \mathrm{L} 2 / 3 \\
\text { neurons }\end{array}$ & TBS & eCB signaling; mGluR5 & Jiang et al. 2010 \\
\hline $\begin{array}{l}\text { Visual cortex } \\
\text { (mouse) }\end{array}$ & LTP & $\begin{array}{l}\text { Excitatory inputs on fast } \\
\text { spiking GABAergic } \\
\text { interneurons }\end{array}$ & & $\begin{array}{l}\text { mGluR5 (but not mGluR1), } \\
\text { postsynaptic calcium, } \\
\text { NMDAR-independent }\end{array}$ & Sarihi et al. 2008 \\
\hline $\begin{array}{l}\text { Somatosensory } \\
\text { (barrel) cortex } \\
\text { (rat) }\end{array}$ & LTD & $\begin{array}{l}\text { Excitatory inputs to } \mathrm{L} 2 / 3 \\
\text { neurons }\end{array}$ & STDP pairing protocol & $\begin{array}{l}\text { eCB signaling, group I mGluR; } \\
\text { postsynaptic } \mathrm{Ca}^{2+} ; \\
\text { presynaptic NMDAR }\end{array}$ & $\begin{array}{l}\text { Bender et al. 2006; Nevian and } \\
\text { Sakmann } 2006\end{array}$ \\
\hline $\begin{array}{l}\text { Sensory-motor } \\
\text { cortex (mouse) }\end{array}$ & LTP & $\begin{array}{l}\text { Excitatory inputs on } \\
\text { somatostatin-expressing } \\
\text { interneurons }\end{array}$ & TBS & $\begin{array}{l}\text { NMDAR-independent, } \\
\text { postsynaptic calcium- } \\
\text { independent, PKA dependent }\end{array}$ & Chen et al. 2009 \\
\hline $\begin{array}{l}\text { Somatosensory } \\
\text { cortex (rat) }\end{array}$ & LTP & $\begin{array}{l}\text { Pyramidal cell on LTS } \\
\text { GABAergic interneurons }\end{array}$ & STDP pairing protocol & NMDAR-dependent & Lu et al. 2007 \\
\hline $\begin{array}{l}\text { Somatosensory } \\
\text { cortex (rat) }\end{array}$ & LTD & $\begin{array}{l}\text { Pyramidal cell on LTS } \\
\text { GABAergic interneurons }\end{array}$ & STDP pairing protocol & $\begin{array}{l}\text { mGluR-dependent, NMDAR/ } \\
\text { CB1R-independent }\end{array}$ & Lu et al. 2007 \\
\hline $\begin{array}{l}\text { Prefrontal cortex } \\
\quad \text { (mouse) }\end{array}$ & LTD & $\begin{array}{l}\text { Excitatory inputs } \mathrm{L} 2 / 3 \text { to } \\
\text { L5/6 neurons }\end{array}$ & $\begin{array}{l}\text { Moderate } 10 \mathrm{~Hz} \\
\text { stimulation for } 10 \mathrm{~min}\end{array}$ & $\begin{array}{l}\text { eCB signaling; postsynaptic } \\
\mathrm{Ca}^{2+} ; \text { mGluR5 }\end{array}$ & Lafourcade et al. 2007 \\
\hline $\begin{array}{l}\text { Prefrontal cortex } \\
\quad \text { (rat, mouse) }\end{array}$ & LTD & $\begin{array}{l}\text { GABAergic inputs to L5/6 } \\
\text { neuorns }\end{array}$ & $\begin{array}{l}\text { Moderate } 5 \mathrm{~Hz} \\
\text { stimulation for } \\
5-10 \mathrm{~min}\end{array}$ & $\begin{array}{l}\text { eCB signaling; group I mGluR; } \\
\text { presynaptic D2R }\end{array}$ & Chiu et al. 2010 \\
\hline $\begin{array}{l}\text { Thalamus } \\
\text { (mouse) }\end{array}$ & LTP & $\begin{array}{l}\text { Cortical inputs to } \\
\text { ventrobasal neurons }\end{array}$ & $(100 \mathrm{stim}, 10 \mathrm{~Hz}) \times 6$ & NMDAR-independent & $\begin{array}{l}\text { Castro-Alamancos and Calcagnotto } \\
1999\end{array}$ \\
\hline $\begin{array}{l}\text { Hippocampus } \\
\text { (mouse, rat, } \\
\text { guinea pig) }\end{array}$ & LTP & $\begin{array}{l}\text { Mossy fiber to CA3 } \\
\text { pyramidal cell }\end{array}$ & HFS $(25-100 \mathrm{~Hz})$ & $\begin{array}{l}\text { cAMP/PKA, R-type VGCC, } \\
\text { NMDAR-independent }\end{array}$ & $\begin{array}{l}\text { Harris and Cotman 1986; Zalutsky } \\
\text { and Nicoll 1990; Huang et al. } \\
\text { 1994; Weisskopf et al. 1994; Xiang } \\
\text { et al. 1994; Yeckel et al. 1999 (see } \\
\text { text for additional references) }\end{array}$ \\
\hline
\end{tabular}




\section{$\$_{\mathrm{CSH}}^{\infty}$ Cold Spring Harbor Perspectives in Biology \\ फం $\infty^{\circ}$ www.cshperspectives.org}

Table 1. Continued

\begin{tabular}{|c|c|c|c|c|c|}
\hline $\begin{array}{l}\text { Brain area } \\
\text { (species) }\end{array}$ & LTP/LTD & Synapse type & Induction protocol ${ }^{\mathrm{a}}$ & Induction requirements & References $^{\mathrm{b}}$ \\
\hline Dentate (rat) & LTP & $\begin{array}{l}\text { Mossy fiber to dentate } \\
\text { gyrus basket cell }\end{array}$ & $\begin{array}{l}30 \mathrm{~Hz} \text { bursts paired with } \\
\text { postsynaptic action } \\
\text { potentials }\end{array}$ & $\begin{array}{l}\text { PKC-dependent, } \\
\text { PKA-independent, } \\
\text { postsynaptic calcium }\end{array}$ & Alle et al. 2001 \\
\hline Dentate (rat) & LTP & Mossy fiber to mossy cells & HFS $(100 \mathrm{~Hz})$ & NMDAR-independent & Lysetskiy et al. 2005 \\
\hline $\begin{array}{l}\text { Hippocampus } \\
\text { (mouse, rat) }\end{array}$ & LTD & $\begin{array}{l}\text { Mossy fiber to s.lucidum } \\
\text { interneurons }\end{array}$ & HFS $(100 \mathrm{~Hz})$ & $\begin{array}{l}\text { Postsynaptic } \mathrm{Ca}^{2+} \text { via } \\
\text { CP-AMPARs, presynaptic } \\
\text { mGluR7, PKC }\end{array}$ & $\begin{array}{l}\text { Maccaferri et al. 1998; Lei and } \\
\text { McBain 2004; Pelkey et al. 2005, } \\
2006\end{array}$ \\
\hline $\begin{array}{l}\text { Hippocampus } \\
\quad \text { (rat) }\end{array}$ & LTP & $\begin{array}{l}\text { Mossy fiber to CA3 } \\
\text { s.lacunosum moleculare } \\
\text { interneurons }\end{array}$ & HFS $(100 \mathrm{~Hz})$ & $\begin{array}{l}\text { Postsynaptic } \mathrm{Ca}^{2+}, \text { L-type } \\
\text { VGCC, NMDAR-inde- } \\
\text { pendent, postsynaptic PKA }\end{array}$ & Galvan et al. 2008, 2010 \\
\hline $\begin{array}{l}\text { Hippocampus } \\
\quad \text { (neonatal rat) }\end{array}$ & LTP & $\begin{array}{l}\text { Immature mossy fiber to } \\
\text { CA3 pyramidal cell }\end{array}$ & STDP pairing protocol & $\begin{array}{l}\text { Postsynaptic } \mathrm{Ca}^{2+} \text {; L-type } \\
\text { VGCC; NMDAR- } \\
\text { independent; BDNF/trkB; } \\
\text { postsynaptic cAMP/PKA }\end{array}$ & Sivakumaran et al. 2009 \\
\hline $\begin{array}{l}\text { Hippocampus } \\
\text { (rat) }\end{array}$ & LTP & $\begin{array}{l}\text { Excitatory inputs on CA1 } \\
\text { interneurons }\end{array}$ & HFS $(100 \mathrm{~Hz})$, TBS & $\begin{array}{l}\text { Postsynaptic } \mathrm{Ca}^{2+} \text { via } \\
\text { CP-AMPARs, NMDAR- } \\
\text { independent }\end{array}$ & $\begin{array}{l}\text { Lamsa et al. 2007; Oren et al. 2009; } \\
\text { Nissen et al. } 2010\end{array}$ \\
\hline $\begin{array}{l}\text { Hippocampus } \\
\quad \text { (rat) }\end{array}$ & LTP & $\begin{array}{l}\text { Excitatory inputs on CA1 } \\
\text { interneurons }\end{array}$ & $\begin{array}{l}\text { TBS paired with } \\
\text { postsynaptic } \\
\text { depolarization }\end{array}$ & $\begin{array}{l}\text { Postsynaptic } \mathrm{Ca}^{2+} \text { and } \\
\text { mGluR1 activation }\end{array}$ & $\begin{array}{l}\text { Perez et al. 2001; Lapointe et al. 2004; } \\
\text { Topolnik et al. } 2006\end{array}$ \\
\hline Hippocampus & LTD & $\begin{array}{l}\text { Excitatory inputs on CA1 } \\
\text { interneurons }\end{array}$ & HFS $(100 \mathrm{~Hz})$ & $\begin{array}{l}\text { Retrograde signaling by } \\
\text { 12-(S)-HPETE, presynaptic } \\
\text { TRPV1, group I mGluR, } \\
\text { NMDAR-independent }\end{array}$ & Gibson et al. 2008 \\
\hline $\begin{array}{l}\text { Subiculum } \\
\text { (mouse, rat) }\end{array}$ & LTP & $\begin{array}{l}\text { CA1-subiculum pyramidal } \\
\text { cell }\end{array}$ & HFS $(100 \mathrm{~Hz})$ & $\begin{array}{l}\text { cAMP/PKA, postsynaptic } \\
\mathrm{Ca}^{2+} \text {-independent }\end{array}$ & Kokaia 2000; Wozny et al. 2008a,b \\
\hline $\begin{array}{l}\text { Hippocampus } \\
\text { (mouse) }\end{array}$ & LTP & $\begin{array}{l}\text { Schaffer collateral-CA1 } \\
\text { pyramidal cell }\end{array}$ & HFS $(200 \mathrm{~Hz})$ & $\begin{array}{l}\text { Postsynaptic } \mathrm{Ca}^{2+}, \text { L-type } \\
\text { VGCC }\end{array}$ & $\begin{array}{l}\text { Zakharenko et al. 2001; Bayazitov } \\
\text { et al. } 2007\end{array}$ \\
\hline $\begin{array}{l}\text { Hippocampus } \\
\text { (mouse) }\end{array}$ & LTP & $\begin{array}{l}\text { Perforant path-CA1 } \\
\text { pyramidal cells }\end{array}$ & HFS $(200 \mathrm{~Hz})$ & $\begin{array}{l}\text { Postsynaptic NMDARs; L-type, } \\
\text { T-type VGCCs }\end{array}$ & Ahmed and Siegelbaum 2009 \\
\hline
\end{tabular}




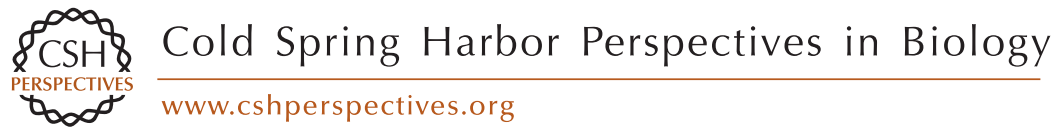

\begin{tabular}{|c|c|c|c|c|}
\hline $\begin{array}{l}\text { Hippocampus } \\
\text { (rat, mouse) }\end{array}$ & LTD & $\begin{array}{l}\text { Inhibitory inputs to CA1 } \\
\text { pyramidal cells }\end{array}$ & HFS, TBS & $\begin{array}{l}\text { eCB signaling; group I } \\
\text { mGluRs; cAMP/PKA; } \\
\text { postsynaptic } \mathrm{Ca}^{2+} \text { and } \\
\text { NMDAR-independent }\end{array}$ \\
\hline $\begin{array}{l}\text { Cerebellum } \\
\text { (mouse, rat, } \\
\text { guinea pig) }\end{array}$ & LTP & $\begin{array}{l}\text { Parallel fiber to Purkinje } \\
\text { cell }\end{array}$ & $\begin{array}{l}\text { 4-10 Hz stimulation } \\
(\text { e.g., } 8 \mathrm{~Hz}, 30 \mathrm{~Hz})\end{array}$ & $\begin{array}{l}\text { cAMP/PKA; NMDAR and } \\
\text { postsynaptic } \\
\mathrm{Ca}^{2+} \text {-independent }\end{array}$ \\
\hline $\begin{array}{l}\text { Cerebellum } \\
\text { (mouse) }\end{array}$ & LTD & $\begin{array}{l}\text { Parallel fiber to Purkinje } \\
\text { cell }\end{array}$ & $\begin{array}{l}4 \mathrm{~Hz} \text {, in the presence of } \\
\text { PKA inhibitor }\end{array}$ & eCB signaling NMDAR \\
\hline Cerebellum (rat) & LTP & $\begin{array}{l}\text { Parallel fiber to molecular } \\
\text { layer interneuron }\end{array}$ & $8 \mathrm{~Hz}$ stimulation for $30 \mathrm{~s}$ & cAMP/PKA \\
\hline Cerebellum (rat) & LTP & Parallel fiber to stellate cell & $\begin{array}{l}\text { Pairing protocol: } 2 \mathrm{~Hz} \\
\text { for } 60 \mathrm{~s} \text {, postsynaptic } \\
\text { depolarization }\end{array}$ & $\begin{array}{l}\text { cAMP-independent, } \\
\text { NO-dependent }\end{array}$ \\
\hline Cerebellum (rat) & LTD & Parallel fiber to stellate cell & $4 \times 25$ stim at $30 \mathrm{~Hz}$ & $\begin{array}{l}\text { Postsynaptic } \mathrm{Ca}^{2+}, \mathrm{CP}- \\
\text { AMPARs, mGluR1, eCB } \\
\text { retrograde signaling, } \\
\text { NMDAR-independent }\end{array}$ \\
\hline $\begin{array}{l}\text { Cerebellum } \\
\text { (mouse) }\end{array}$ & LTP & Stellate cell-stellate cell & $\begin{array}{l}\text { HFS }(100 \mathrm{~Hz}) \text { of parallel } \\
\text { fibers }\end{array}$ & Presynaptic NMDARs \\
\hline $\begin{array}{l}\text { Lateral amygdala } \\
\quad \text { (rat, mouse) }\end{array}$ & LTP & $\begin{array}{l}\text { Cortico-lateral amygdala } \\
\text { neurons }\end{array}$ & $\begin{array}{l}\text { Simultaneous repetitive } \\
\text { stimulation (Poisson } \\
\text { train, } 30 \mathrm{~Hz} \text { average) } \\
\text { of thalamic and cortical } \\
\text { afferents }\end{array}$ & $\begin{array}{l}\text { Presynaptic NMDAR, } \\
\text { cAMP/PKA }\end{array}$ \\
\hline $\begin{array}{l}\text { Lateral amygdala } \\
\quad \text { (rat) }\end{array}$ & LTP & $\begin{array}{l}\text { Cortico-lateral amygdala } \\
\text { neurons }\end{array}$ & $\begin{array}{l}\text { Pairing protocol }(80 \\
\text { stim, } 2 \mathrm{~Hz})+30 \mathrm{mV} \\
\text { postsynaptic } \\
\text { depolarization }\end{array}$ & $\begin{array}{l}\text { Postsynaptic } \mathrm{Ca}^{2+}, \mathrm{NMDAR}, \\
\text { L-type VGCC }\end{array}$ \\
\hline $\begin{array}{l}\text { Lateral amygdala } \\
\text { (rat) }\end{array}$ & LTP & $\begin{array}{l}\text { Thalamic-lateral amygdala } \\
\text { neurons }\end{array}$ & HFS $(100 \mathrm{~Hz})$ & $\begin{array}{l}\text { Postsynaptic } \mathrm{Ca}^{2+} \text {, presynaptic } \\
\text { cAMP/PKA }\end{array}$ \\
\hline $\begin{array}{l}\text { Lateral amygdala } \\
\quad \text { (rat) }\end{array}$ & LTP & $\begin{array}{l}\text { Thalamic-lateral amygdala } \\
\text { neurons }\end{array}$ & $\begin{array}{l}\text { PP stimulation ( } 50 \mathrm{~ms} \\
\text { ISI), } 2 \mathrm{~Hz} \text { for } 2 \mathrm{~min}\end{array}$ & $\begin{array}{l}\text { Presynaptic } \mathrm{Ca}^{2+} \\
\text { GluK1-containing KAR, } \\
\text { NMDAR-independent }\end{array}$ \\
\hline
\end{tabular}

Chevaleyre and Castillo 2003, 2002

Sakurai 1987; Shibuki and Okada 1992; Salin et al. 1996b; Storm et al. 1998; Linden and Ahn 1999; Bender et al. 2009

Qiu and Knopfel 2009

Bender et al. 2009; Rancillac and Crepel 2004

Rancillac and Crepel 2004

Soler-Llavina and Sabatini 2006

Liu and Lachamp 2006; Lachamp et al. 2009

Humeau et al. 2003; Fourcaudot et al. 2008, 2009

Tsvetkov et al. 2002

Huang and Kandel 1998

Shin et al. 2010 
Table 1. Continued

\begin{tabular}{|c|c|c|c|c|c|}
\hline $\begin{array}{l}\text { Brain area } \\
\text { (species) }\end{array}$ & LTP/LTD & Synapse type & Induction protocol $^{\mathrm{a}}$ & Induction requirements & References $^{\mathrm{b}}$ \\
\hline $\begin{array}{l}\text { Central amygdala } \\
\text { (guinea pig) }\end{array}$ & LTP & $\begin{array}{l}\text { Thalamic-central } \\
\text { amygdala neurons }\end{array}$ & $\begin{array}{l}\text { HFS }(100 \mathrm{~Hz}) \text { paired with } \\
\text { brief suprathreshold } \\
\text { depolarization }\end{array}$ & Presynaptic NMDAR & Samson and Pare 2005 \\
\hline $\begin{array}{l}\text { Central amygdala } \\
\quad \text { (rat) }\end{array}$ & LTP & $\begin{array}{l}\text { Nociceptive inputs to } \\
\text { central amygdala } \\
\text { neurons }\end{array}$ & HFS $(100 \mathrm{~Hz})$ & $\begin{array}{l}\text { cAMP/PKA; } \\
\text { NMDAR-independent }\end{array}$ & Lopez de Armentia and Sah 2007 \\
\hline $\begin{array}{l}\text { Lateral amygdala } \\
\text { (mouse) }\end{array}$ & LTD & $\begin{array}{l}\text { GABAergic inputs to } \\
\text { lateral amygdala }\end{array}$ & LFS $(1 \mathrm{~Hz})$ & $\begin{array}{l}\text { eCB signaling; mGluR1; } \\
\text { postsynaptic PKA activity }\end{array}$ & $\begin{array}{l}\text { Marsicano et al. 2002; Azad et al. } \\
2004\end{array}$ \\
\hline $\begin{array}{l}\text { Dorsal striatum } \\
\quad(\text { rat, mouse })\end{array}$ & LTD & $\begin{array}{l}\text { Glutamatergic cortical } \\
\text { inputs to medium } \\
\text { spiny neurons }\end{array}$ & $\begin{array}{l}\text { HFS }(100 \mathrm{~Hz}), \text { STDP } \\
\text { pairing protocol }\end{array}$ & $\begin{array}{l}\text { eCB signaling; group I mGluR; } \\
\text { postsynaptic } \mathrm{Ca}^{2+}\end{array}$ & $\begin{array}{l}\text { Gerdeman et al. 2002; Kreitzer and } \\
\text { Malenka 2007; Shen et al. } 2008\end{array}$ \\
\hline $\begin{array}{l}\text { Nucleus } \\
\text { accumbens } \\
\text { (mouse) }\end{array}$ & LTD & $\begin{array}{l}\text { Glutamatergic cortical } \\
\text { afferents to nucleus } \\
\text { accumbens }\end{array}$ & $\begin{array}{l}\text { Moderate } 13 \mathrm{~Hz} \\
\text { stimulation for } 10 \\
\text { min }\end{array}$ & $\begin{array}{l}\text { eCB signaling; mGluR5; } \\
\text { postsynaptic } \mathrm{Ca}^{2+}\end{array}$ & Robbe et al. 2002b \\
\hline $\begin{array}{l}\text { Nucleus } \\
\text { accumbens } \\
\text { (mouse) }\end{array}$ & LTD & $\begin{array}{l}\text { Cortical afferents to } \\
\text { nucleus accumbens }\end{array}$ & HFS $(100 \mathrm{~Hz})$ & $\begin{array}{l}\text { mGluR2/3, cAMP/PKA } \\
\text { signaling }\end{array}$ & Robbe et al. 2002a \\
\hline $\begin{array}{l}\text { Ventral tegmental } \\
\text { area (rat) }\end{array}$ & LTD & $\begin{array}{l}\text { GABAergic inputs to } \\
\text { dopamine neurons }\end{array}$ & $\begin{array}{l}\text { Moderate } 10 \mathrm{~Hz} \\
\text { stimulation for } 5 \\
\text { min }\end{array}$ & $\begin{array}{l}\text { eCB signaling; group I mGluR, } \\
\text { D2R }\end{array}$ & Pan et al. 2008 \\
\hline $\begin{array}{l}\text { Ventral tegmental } \\
\text { area (rat) }\end{array}$ & LTP & $\begin{array}{l}\text { GABAergic inputs to } \\
\text { dopamine neurons }\end{array}$ & HFS $(100 \mathrm{~Hz})$ & $\begin{array}{l}\text { Postsynaptic } \mathrm{Ca}^{2+} \text {; NMDAR; } \\
\text { Nitric Oxide/cGMP } \\
\text { signaling }\end{array}$ & Nugent et al. 2007 \\
\hline $\begin{array}{l}\text { Dorsal Cochlear } \\
\text { Nucleus } \\
\text { (mouse) }\end{array}$ & LTD & $\begin{array}{l}\text { Glutamatergic inputs to } \\
\text { Carthwheel GABAergic } \\
\text { interneuron }\end{array}$ & STDP paring protocol & $\begin{array}{l}\text { eCB signaling; group I } \\
\text { mGluR-indpependent }\end{array}$ & Tzounopoulos et al. 2007 \\
\hline $\begin{array}{l}{ }^{\mathrm{a}} \text { Most typical ind } \\
{ }^{\mathrm{b}} \text { Because of space } \\
\text { Abbreviations: } \mathrm{HF} \\
\text { VGCC, voltage-gated }\end{array}$ & n proto & $\begin{array}{l}\text { is indicated. Only examples } \\
\text { t all references are listed (see t } \\
\text { ncy stimulation; TBS, theta-bu } \\
\text { nel, eCB, endocannabinoid; C }\end{array}$ & $\begin{array}{l}\text { timulation; PPF, paired-pulse } \mathrm{f} \\
{ }^{2+} \text {-prmeable; D2R, type } 2 \mathrm{dot}\end{array}$ & $\begin{array}{l}\text { mically induced) LTP/LTD in brain } \\
\text { facilitation; CV, coefficient of variat } \\
\text { pamine receptor; } \mathrm{n} / \mathrm{a} \text {, not available }\end{array}$ & $\begin{array}{l}\text { are listed. } \\
\text { TDP, spike timing-dependent plasticity; }\end{array}$ \\
\hline
\end{tabular}


glutamate release at MF-CA3 synapses is mediated by $\mathrm{N}$ - and $\mathrm{P} / \mathrm{Q}$-type voltage gated $\mathrm{Ca}^{2+}$ channels (VGCCs), MF-LTP can occur with both of these channel types blocked (Castillo et al. 1994). In contrast, R-type channels contribute significantly to MF-LTP, despite playing a minor role in overall presynaptic $\mathrm{Ca}^{2+}$ influx and basal transmission (Breustedt et al. 2003; Dietrich et al. 2003). $\mathrm{Ca}^{2+}$ influx via R-type VGCCs appears to preferentially access presynaptic signals that trigger MF-LTP, as recently suggested for parallel fiber LTP (Myoga and Regehr 2011). Pharmacological manipulations and genetic analyses using knockout mice indicates that presynaptic $\mathrm{Ca}^{2+}$ activates a $\mathrm{Ca}^{2+} /$ calmodulin-dependent adenylyl cyclase, leading to enhanced presynaptic cAMP levels and activation of PKA, which is necessary for MF-LTP (Huang et al. 1994; Weisskopf et al. 1994; Villacres et al. 1998; Wang et al. 2003). PKA then phosphorylates presynaptic substrate(s) to cause a long-lasting increase in transmitter release (see below).

An alternative mechanism for MF-LTP induction has been proposed. The leading event is a postsynaptic $\mathrm{Ca}^{2+}$ enhancement via L-type VGCCs and group I mGluR-stimulated release of $\mathrm{Ca}^{2+}$ from internal stores. $\mathrm{Ca}^{2+}$ mobilizes a retrograde signal in a PKA-dependent manner (Jaffe and Johnston 1990; Kapur et al. 1998; Yeckel et al. 1999). A similar mechanism has recently been reported at some MF to CA3 interneuron synapses (Galvan et al. 2008, 2010). This induction model is consistent with Hebbian MF-LTP (Urban and Barrionuevo 1996) whereby plasticity is triggered by both presynaptic activity that releases glutamate to activate postsynaptic group I mGluRs, and postsynaptic depolarization to activate L-type VGCCs. Numerous studies have not been able to confirm a postsynaptic model of classical MF-LTP induction (for a review, see Nicoll and Schmitz 2005), and as a result, no agreement has yet emerged. Interestingly, at immature MF-CA3 synapses, which mainly release GABA that acts as excitatory neurotransmitter at early developmental stages, correlated presynaptic and postsynaptic activity triggers presynaptically expressed LTP, whose induction requires postsynaptic $\mathrm{Ca}^{2+}$ rise and postsynaptic cAMP/PKA signaling
(Sivakumaran et al. 2009). Given that brain-derived neurotrophic factor (BDNF)/tyrosine kinase $B(\operatorname{trkB})$ signaling is also required, BDNF could act as a retrograde messenger (see below), a possibility that needs to be directly tested. Another mechanism of induction requiring retrograde signaling has been proposed at mature MF-CA3 synapses. The model involves transsynaptic interaction between postsynaptic EphB receptor tyrosine kinases and presynaptic BEphrin ligands resulting, via an unknown mechanism, in a long-lasting increase in transmitter release (Contractor et al. 2002; Armstrong et al. 2006).

MF synapses also express presynaptic LTD. Similar protocols of stimulation commonly used to trigger NMDAR-dependent LTD at SchCA1 synapses also induce a MF-CA3 homosynaptic LTD expressed as a reduction in glutamate release (Kobayashi et al. 1996). The MFCA3 synapse is one of few locations where bidirectional presynaptic LTP/LTD can be observed in the central nervous system. Presynaptic MF-LTD induction is NMDAR-independent and seems to require presynaptic mGluR2 as indicated by studies using nonselective mGluR antagonists and mGluR2 knockout mice (Yokoi et al. 1996; Tzounopoulos et al. 1998; Kobayashi et al. 1999). Intriguingly, none of these manipulations fully abolishes MF-LTD. Exogenous mGluR2 activation is not sufficient for induction and must be associated with MF activity, which presumably provides a $\mathrm{Ca}^{2+}$-dependent signal (Tzounopoulos et al. 1998; Kobayashi et al. 1999). Given that $\mathrm{G}_{\mathrm{i} / \mathrm{o}}$ coupled mGluR2 activation leads to decreased cAMP/PKA activity, MF-LTD could be a reversal of the presynaptic process involved in MF-LTP. Unexpectedly, two recent studies have called into question the induction mechanism underlying MF-LTD. Using more specific and potent group II mGluRs antagonists, as well as mGluR2/3 double knockout mice, these studies still observed presynaptic MF-LTD (Wostrack and Dietrich 2009; Lyon et al. 2011). MF-LTD induced in mGluR2/3 double knockout mice was abolished by pharmacologically blocking kainate receptors (Lyon et al. 2011), raising the intriguing possibility that these receptors, via a metabotropic action, 


\section{P.E. Castillo}

could be involved in the induction of presynaptic MF-LTD (Negrete-Diaz et al. 2007). Further studies are required to determine the precise mechanism of presynaptic MF-LTD.

Other presynaptic forms of plasticity that are mechanistically similar to MF-LTP have been identified in multiple brain areas, including the cerebellum, the amygdala (see Pape and Pare 2010) and subiculum (Table 1) (see Behr et al. 2009). In the cerebellum, repetitive parallel fiber (PF) stimulation triggers presynaptic LTP at PF to Purkinje cell synapses. Induction does not require postsynaptic glutamate receptor activation or $\mathrm{Ca}^{2+}$ rises but, as for MF-LTP, requires CAMP/PKA signaling ( $\mathrm{Sa}$ kurai 1987; Shibuki and Okada 1992; Salin et al. 1996b; Storm et al. 1998; Linden and Ahn 1999; Bender et al. 2009). Similar presynaptic LTP was subsequently observed at PF to molecular layer interneuron synapses (Rancillac and Crepel 2004; Bender et al. 2009). Like MF synapses, PF synapses display bidirectional presynaptic plasticity. Indeed, PF inputs onto both Purkinje cells (Qiu and Knopfel 2009) and molecular layer interneurons (Soler-Llavina and Sabatini 2006) can undergo presynaptic LTD. However, unlike at MF synapses, presynaptic LTD at PF synapses seems to be mediated by endocannabinoids (see below).

Presynaptic LTP/LTD at Excitatory

Synapses onto Interneurons

In addition to CA3 pyramidal cells, MFs establish synapses with multiple classes of interneurons, such as excitatory mossy cells in the hillus, and inhibitory interneurons in both CA3 and dentate gyrus. Although HFS of MFs triggers a presynaptic form of LTP in mossy cells that is reportedly identical to classical MF-LTP in CA3 pyramidal cells (Lysetskiy et al. 2005), a slightly modified stimulation paradigm applied to presynaptic dentate granule cells triggers a form of presynaptic LTP at MF-dentate gyrus basket cells whose induction requires a rise in postsynaptic $\mathrm{Ca}^{2+}$. Because this LTP is expressed presynaptically, a retrograde messenger is required (Alle et al. 2001) but the identity of this messenger remains unknown. Intriguingly, unlike classical MF-LTP in principal neurons, LTP at MF-basket cell synapses requires PKC but not PKA activity (Alle et al. 2001).

Whereas repetitive stimulation triggers presynaptic LTP at both MF-mossy cell and MFbasket cell synapses, a very different picture emerges at MF-interneuron synapses (mainly MF to s. lucidum interneurons, a.k.a. MF-SLIN synapses) (for a review, see McBain 2008). Remarkably, the same stimulation paradigm that induces presynaptic LTP in both principal neurons and mossy cells triggers a NMDAR-independent form of presynaptic LTD at some MF-interneuron synapses (Maccaferri et al. 1998). These synapses were subsequently identified as those expressing $\mathrm{Ca}^{2+}$-permeable (CP), GluR2-lacking AMPARs (Toth et al. 2000; Lei and McBain 2004). Induction of this form of LTD requires a postsynaptic $\mathrm{Ca}^{2+}$ rise via CPAMPARs, and activation of presynaptic mGluR7 receptors, which triggers $\mathrm{PKC}$ and a downregulation of $\mathrm{Ca}^{2+}$ influx through $\mathrm{P} / \mathrm{Q}$-type VGCCs to reduce probability of release (Pelkey et al. 2005, 2006). Activation of mGluR7 is necessary but not sufficient to induce LTD; postsynaptic activity and the associated postsynaptic $\mathrm{Ca}^{2+}$ rise are also required to presumably promote the mobilization of an as yet unidentified retrograde messenger.

Unexpectedly, mGluR7 not only mediates a long-lasting reduction in glutamate release but also acts as a metaplastic switch such that on binding of agonist, mGluR7 is rapidly internalized and delivery of subsequent HFS then triggers a de-depression or LTP of synaptic transmission (Pelkey et al. 2005). It therefore appears that the presence or absence of mGluR7 on the presynaptic surface dictates whether the MF-SLIN synapse weakens or strengthens in response to HFS. The de-depression/LTP unmasked by mGluR7 internalization is caused by an enhancement in glutamate release, the molecular basis of which will be discussed below. Repetitive activation of MFs can also trigger presynaptic LTP on CA3 lacunosum-moleculare interneurons (Galvan et al. 2011). How exactly these multiple forms of synaptic plasticity of MFs on interneurons regulate the CA3 network excitability remains to be determined. 
Several other examples of presynaptic LTP/ LTD have been identified at glutamatergic inputs onto interneurons throughout the brain (Table 1) (for recent, comprehensive reviews see McBain and Kauer 2009; Kullmann and Lamsa 2011). As for the examples discussed above, induction typically requires postsynaptic $\mathrm{Ca}^{2+}$ to rise in an NMDAR-independent manner. A common source includes $\mathrm{Ca}^{2+}$ influx via CP-AMPARs, although L-type VGCCs and group I mGluR-stimulated release of $\mathrm{Ca}^{2+}$ from internal stores may also contribute. What determines the sign of plasticity (i.e., LTP or LTD) at a given synapse is unclear but both postsynaptic and presynaptic factors may contribute.

\section{Presynaptic NMDAR-Dependent Plasticity}

Increasing evidence supports the notion that presynaptic NMDARs (preNMDARs) can regulate transmitter release and play a key role in the induction of presynaptic forms of plasticity (Duguid and Sjostrom 2006; Corlew et al. 2008; Rodriguez-Moreno et al. 2010). Physiological studies strongly suggest that preNMDARs can enhance both spontaneous and evoked transmitter release (glutamate and GABA) at some synapses, and there is anatomical evidence supporting a presynaptic localization (Corlew et al. 2008). A key experiment in support of preNMDAR-dependent forms of plasticity is the demonstration that global antagonism of NMDAR blocks induction, whereas blocking postsynaptic NMDARs (e.g., by loading cells with the NMDAR channel blocker MK-801) has no effect. Like other presynaptic ionotropic receptors (Engelman and MacDermott 2004), preNMDARs facilitate transmitter release most likely by direct depolarization of the presynaptic terminal, by permeating $\mathrm{Ca}^{2+}$, or both. An alternative mechanism not requiring membrane depolarization and $\mathrm{Ca}^{2+}$ influx cannot be discarded. Endogenous glutamate that activates preNMDARs can arise from the same terminal (acting as an autoreceptor) or neighboring terminals (acting as a heteroreceptor), although postsynaptic dendritic release (Duguid and Smart 2004) and release from glia could also contribute (Parpura and Zorec 2010).
In neocortex (visual and somatosensory cortices, see Table 1), there is strong evidence (Sjöstrom et al. 2003; Bender et al. 2006; Nevian and Sakmann 2006; Corlew et al. 2007; Rodriguez-Moreno and Paulsen 2008) that preNMDARs play a key role in the induction of the LTD component of spike timing-dependent plasticity (STDP), an associative form of plasticity in which the precise temporal relationship between presynaptic and postsynaptic activity determines the direction (t-LTP or t-LTD) and the magnitude of the resulting change in synaptic strength (for a recent review, see Caporale and Dan 2008). Induction of preNMDARdependent t-LTD requires postsynaptic $\mathrm{Ca}^{2+}$ rise and activation of group I mGluRs (at least in somatosensory cortex). In addition, this t-LTD is expressed presynaptically as a long-lasting reduction in transmitter release, implicating a retrograde signal, which has been identified as an endogenous cannabinoid (Sjöstrom et al. 2003; Bender et al. 2006; Nevian and Sakmann 2006). As discussed below, endocannabinoids (eCB) are well-established retrograde messengers mediating most known forms of presynaptic LTD in the brain (Heifets and Castillo 2009). Because eCBs mediate their effects by targeting presynaptic cannabinoid receptors, an obvious question is how these receptors interact with NMDARs at the presynaptic terminal to induce t-LTD. PreNMDARs could have an instructive or regulatory role in t-LTD. In the first case, given the dual requirement of depolarization and glutamate binding for NMDAR gating, preNMDARs act as coincidence detectors of presynaptic action potential-mediated depolarization and glutamate release. As expected, t-LTD only occurs if these receptors are activated within a narrow interval, although presynaptic cannabinoid receptors may also contribute to set this time window for t-LTD (Sjöstrom et al. 2003; Duguid and Sjostrom 2006). In a regulatory role, preNMDARs somehow facilitate induction but the coincidence detection occurs postsynaptically as a result of group I mGluR activation by glutamate and postsynaptic $\mathrm{Ca}^{2+}$ rise via L-type VGCCs (Bender et al. 2006; Nevian and Sakmann 2006). In this case, mGluRs and $\mathrm{Ca}^{2+}$ would act synergistically to 
P.E. Castillo

mobilize eCBs as shown in other systems (Hashimotodani et al. 2007). These examples in neocortex, suggest that the precise interaction of preNMDARs and $\mathrm{eCB}$ signaling in setting the characteristic time window for t-LTD induction is synapse-specific. It will be interesting to know the generality of preNMDAR-dependent t-LTD in other brain areas especially because preNMDARs expression and subunit composition can be developmentally regulated (Corlew et al. 2008; Larsen et al. 2011).

Several studies have shown that activation of preNMDARs mediates other forms of presynaptic LTP/LTD at both excitatory and inhibitory synapses. Two forms of preNMDARdependent LTP, both expressed presynaptically, have been reported in the amygdala. In the lateral amygdala (LA), repeated coincident stimulation of converging cortical and thalamic excitatory afferents on LA projection neurons induces associative LTP at cortical but not thalamic inputs (Humeau et al. 2003). In addition, induction is independent of postsynaptic activity, including depolarization, $\mathrm{Ca}^{2+}$ rise and activation of postsynaptic NMDARs, but requires cAMP/PKA signaling (Fourcaudot et al. 2008). A potential mechanism for this heterosynaptic associative form of plasticity is that glutamate released by thalamic afferents might directly activate preNMDARs on cortical presynaptic terminals (adding to the homosynaptic activation by glutamate released from these terminals), thereby promoting presynaptic $\mathrm{Ca}^{2+}$ increase, which, like for other forms of presynaptic LTP (e.g., MF-LTP), triggers a long-lasting cAMP/PKA-dependent increase in transmitter release. The other form of preNMDAR-dependent LTP in amygdala has been reported at thalamic afferents on medial sector neurons in the central nucleus (Samson and Pare 2005). Unlike cortical-LA LTP, LTP in central amygdala is homosynaptic and nonassociative, and much less is known about its molecular mechanism of induction.

PreNMDAR-dependent LTP and LTD have also been reported at GABAergic synapses (Lien et al. 2006; Liu et al. 2007). In rodent cerebellar cortex, glutamate released from parallel fibers induces a long-lasting increase of GABA release from stellate cells, presumably by activating preNMDARs on their terminals (Liu and Lachamp 2006). This heterosynaptic form of LTP also requires cAMP/PKA signaling (Lachamp et al. 2009). Finally, in the developing Xenopus retinotectal system, light stimuli or theta burst stimulation of the optic nerve triggers presynaptic LTD of GABAergic synaptic transmission on tectal neurons (Lien et al. 2006). Activation of preNMDARs is necessary but not sufficient for induction. Coincident interneuron activity is also required, and such activity presumably provides the required depolarization for preNMDAR gating as well as $\mathrm{Ca}^{2+}$ influx through presynaptic VGCCs that may also contribute to the inhibitory LTD at hippocampal synapses (Heifets et al. 2008). It remains to be seen whether this type of heterosynaptic LTD of GABAergic transmission also occurs in the mammalian brain.

\section{Retrograde Signaling and Presynaptic LTD/LTP}

Presynaptic forms of plasticity that include a postsynaptic step for their induction also require some form of retrograde communication from the postsynaptic to the presynaptic cell (Fig. 1). Such communication is typically mediated by diffusible retrograde messengers, substances that are released on activity from dendrites and the cell body of neurons and, by targeting the presynaptic terminals, modify transmitter release in a long-lasting manner (Tao and Poo 2001; Regehr et al. 2009). Extensive experimental evidence shows that this mechanism is involved in several forms of presynaptic LTP/LTD at both excitatory and inhibitory synapses (Table 1). A wide range of retrograde messengers have been identified in the brain, including lipid derivatives, gases, peptides, conventional transmitters (e.g., glutamate and GABA), and growth factors (Regehr et al. 2009). Release of retrograde messengers is usually triggered by postsynaptic $\mathrm{Ca}^{2+}$ rises, but $\mathrm{Ca}^{2+}$-independent release can also occur. Depending on their chemical nature, retrograde messengers are released in a vesicular or nonvesicular manner. Although there is good agreement 
that some of these messengers play an essential role in triggering presynaptic LTP/LTD, the ultimate effectors mediating such changes are commonly unknown. A much less explored mechanism, albeit with potentially great relevance for presynaptic forms of plasticity, involves adhesion proteins that span the synaptic cleft (Futai et al. 2007; Gottmann 2008). Little is known about this transsynaptic mechanism in LTP/LTD beyond a few examples (Contractor et al. 2002; Armstrong et al. 2006) and it will not be considered further here.

The idea that retrograde signaling could mediate long-term synaptic plasticity LTP in particular is not new. This mechanism received a great deal of attention in the early 1990s during an intense "pre vs. post" debate regarding the expression locus of NMDAR-dependent LTP. Several diffusible retrograde messengers emerged as mediators of this form of plasticity, including arachidonic acid (Williams et al. 1989), platelet-activating factor (Kato et al. 1994), and gases such as carbon monoxide and nitric oxide (NO) (Zhuo et al. 1993, 1994; Son et al. 1996; Hawkins et al. 1998). Not surprisingly, in the field of synaptic plasticity many of the studies providing experimental evidence for these messengers also generated a great deal of controversy and contradictory results. To mention just one example, NO was strongly implicated as being the retrograde messenger mediating LTP at the Schaffer collateral to CA1 pyramidal cell synapse (for a recent review, see Feil and Kleppisch 2008). However, subsequent studies not only challenged the experimental evidence, but even the need for a retrograde signal in this form of LTP (for a review on this topic, see Kerchner and Nicoll 2008). It is worth noting that classical NMDAR-dependent LTP is not a homogenous phenomenon, and temporally overlapping processes that include a slowly developing presynaptic component and rapidly developing postsynaptic component have been identified (Lisman and Raghavachari 2006; Bayazitov et al. 2007). Although the early postsynaptically expressed phase may occur in the absence of retrograde signaling, such signaling may be important for a late presynaptically expressed LTP (Bayazitov et al. 2007).
The interest in retrograde signaling in presynaptic forms of LTP/LTD has intensified in recent years with the discovery of novel retrograde messengers as mediators of synaptic plasticity and the growing recognition of their widespread nature (Alger 2002; Regehr et al. 2009). In addition, retrograde signaling mediates multiple forms of long-term plasticity at inhibitory synapses throughout the brain, certainly expanding the number of synapse expressing presynaptic LTP/LTD (Castillo et al. 2011). As discussed above, there are several forms of presynaptic LTP/LTD, at both excitatory and inhibitory synapses, where the action of a retrograde messenger is assumed. Here, presynaptic forms of LTP/LTD mediated by an identified retrograde messenger will be briefly discussed.

\section{Endocannabinoid-Mediated LTD}

Endocannabinoids (eCB) mediate one of the clearest examples of presynaptically expressed LTD in the brain (Heifets and Castillo 2009). These retrograde messengers are lipids synthesized from membrane precursors, and two of the best characterized eCBs are $\mathrm{N}$-arachidonoylethanolamide (anandamide, AEA) and 2arachidonoylglycerol (2-AG). Neuronal activity releases eCBs from the postsynaptic compartment, which travel backward to activate the presynaptic type 1 cannabinoid receptor (CB1R, a $\mathrm{G}_{\mathrm{i} / \mathrm{o}}$ protein coupled receptor widely expressed in the brain), thereby suppressing neurotransmitter release at both glutamatergic and GABAergic synapses in a transient and a longterm manner (Chevaleyre et al. 2006; Kano et al. 2009). Multiple examples of eCB-mediated LTD (eCB-LTD) have been identified throughout the mammalian brain (see Table 1) (Heifets and Castillo 2009). Although the pattern of afferent activity may differ between brain regions, induction of eCB-LTD typically begins with a transient increase in activity at glutamatergic afferents and a concomitant postsynaptic release of eCBs from a target neuron. By an unclear mechanism that may include an unidentified membrane transporter, eCBs then travel retrogradely across the synaptic cleft to activate CB1Rs on the presynaptic terminals of either 


\section{P.E. Castillo}

the original glutamatergic afferent (homosynaptic eCB-LTD) or nearby GABAergic afferents (heterosynaptic eCB-LTD) (Chevaleyre et al. 2006). eCB release occurs via two separate postsynaptic processes (Piomelli 2003), activation of $\mathrm{G}_{\mathrm{q}}$ - protein coupled metabotropic receptors (typically group I mGluRs and muscarinic acetylcholine receptors) and depolarization-induced $\mathrm{Ca}^{2+}$ influx via VGCCs. Both pathways contribute to eCB-LTD induction (Heifets and Castillo 2009). The metabotropic pathway engages phospholipase $\mathrm{C}$ (PLC) and diacylglycerol lipase (DGL), which produce the eCB 2-AG. Most forms of eCB-LTD require postsynaptic $\mathrm{Ca}^{2+}$ increase, which likely facilitates eCB production by activating $\mathrm{Ca}^{2+}$-dependent enzymes, including PLC. Importantly, the metabotropic and $\mathrm{Ca}^{2+}$-driven mechanisms can act independently, or synergistically to promote $\mathrm{eCB}$ release and $\mathrm{eCB}-$ mediated plasticity ( $\mathrm{Ha}-$ shimotodani et al. 2007; Heifets and Castillo 2009).

At the presynaptic side, $\mathrm{CB} 1 \mathrm{R}$ activation is required for eCB-LTD induction but once plasticity is established it becomes CB1R-independent (Chevaleyre and Castillo 2003; Ronesi et al. 2004). Typically, induction of eCB-LTD requires that CB1Rs be activated for several minutes (Chevaleyre et al. 2006), suggesting that a slow, and probably metabolic process must occur at the presynaptic terminal for eCB-LTD consolidation. Because eCB-LTD requires PKA activity (Chevaleyre et al. 2007; Mato et al. 2008), and CB1Rs are negatively coupled to cAMP/PKA, such process is likely mediated by the $\alpha_{i / o}$ limb of the CB1R G-protein signaling cascade. Of note, transient activation of CB1Rs suppresses transmitter release by inhibiting presynaptic VGCCs, an effect likely mediated by the $G_{\beta \gamma}$ limb (Wilson et al. 2001). Another relevant property of eCB-LTD is that CB1R activation alone may not be sufficient for induction (Heifets and Castillo 2009). In neocortex, using spike timing-dependent protocols of induction, it has been shown that coincident activation of preNMDARs is also required (Sjöstrom et al. 2003; Bender et al. 2006; Nevian and Sakmann 2006). Presynaptic activity is also necessary for induction in the hippocampus (Heifets et al. 2008) and dorsal striatum (Singla et al. 2007). Together, these observations suggest that $\mathrm{Ca}^{2+}$ influx via preNMDARs in neocortex, or via presynaptic VGCCs in hippocampus and dorsal striatum, may contribute to the PKA-dependent metabolic process mediating eCB-LTD. In support of this possibility is the observation that induction of eCB-LTD in the hippocampus also requires the activation of the $\mathrm{Ca}^{2+}$-sensitive phosphatase calcineurin, likely shifting the balance of kinase (e.g., PKA) and phophatase activity in the presynaptic terminal (Heifets et al. 2008). Finally, CB1Rs can interact with other signaling systems to regulate eCB-LTD induction. CB1R and type 2 dopamine receptor (D2R), which share a common signaling pathway by inhibiting adenylyl cyclase, act synergistically to induce eCB-LTD of inhibitory transmission in the prefrontal cortex (Chiu et al. 2010) and ventral tegmental area (Pan et al. 2008). In contrast, BDNF/TrkB signaling, presumably by inhibiting CB1R function, suppresses eCB-LTD induction at excitatory synapses in visual cortex (Huang et al. 2008). These examples clearly illustrate how multiple interactions between modulatory systems can occur at the presynaptic terminal to regulate eCB-LTD induction.

\section{Retrograde Signaling beyond Endocannabinoids}

Recent studies have provided additional evidence in support of previously identified retrograde messengers as mediators of unconventional forms of presynaptically expressed LTP/ LTD. In the hippocampus, a form of presynaptic LTD on CA1 interneurons known to require retrograde signaling for induction (McMahon and Kauer 1997), has recently been reported to be mediated by a derivative of arachidonic acid acting on presynaptic TRPV1 channels (Gibson et al. 2008). This form of plasticity is triggered by HFS of Schaffer collaterals, the same induction protocol typically used to trigger LTP at Sch-CA1 synapses. Activation of postsynaptic group I mGluRs by glutamate released during tetanus generates arachidonic acid, which is 
rapidly converted to 12-(S)-HPETE by 12-lipoxygenase. 12-(S)-HPETE is a membrane-permeable lipid with a short half-life that travels retrogradely across the synapse, in which it activates TRPV1 receptors on presynaptic glutamatergic nerve terminals. Activation of TRPV1 receptors is necessary and sufficient for the induction of this form of LTD. The precise mechanism by which TRPV1 triggers a longlasting reduction of glutamate release remains unknown but it has been speculated that $\mathrm{Ca}^{2+}$ entry through the TRPV1 channel could activate a signaling cascade responsible for LTD (Gibson et al. 2008). A similar form of TRPV1-dependent LTD has recently been reported in the developing superior colliculus (Maione et al. 2009). It is worth noting that 12-(S)-HPETE has also been implicated in mGluR-dependent LTD at hippocampal Sch CA1 synapses (Feinmark et al. 2003), a form of plasticity with a presynaptic component of expression (Bolshakov and Siegelbaum 1994; Oliet et al. 1997; Zakharenko et al. 2002). The potential 12-(S)-HPETE target(s) that mediate this form of LTD are also unknown.

Neurotrophins such as brain-derived neurotrophic factor (BDNF) have been shown to modulate both excitatory and inhibitory transmission (Lessmann et al. 2003; Lu 2003; Blum and Konnerth 2005). There is also evidence that BDNF can be secreted from dendritic compartments in response to neuronal activity to act as a retrograde messenger and regulate transmitter release (Du and Poo 2004; Magby et al. 2006; Kuczewski et al. 2010). Recent studies have provided evidence for a retrograde action of dendritically released BDNF to potentiate GABAergic release in the visual cortex (Inagaki et al. 2008), hippocampus (Gubellini et al. 2005; Sivakumaran et al. 2009) and optic tectum (Liu et al. 2007). Although the induction protocols vary between brain regions, a postsynaptic $\mathrm{Ca}^{2+}$ rise is invariably required, which presumably enables BDNF secretion (Lessmann et al. 2003). Although the long-lasting enhancement of GABA release likely results from the activation of presynaptic TrkB receptors by BDNF, how exactly TrkB/BDNF signaling enhances transmitter release is unknown. Notably, the aforementioned studies used preparations in early stages of development. Whether BDNF retrograde signaling could also mediate presynaptic plasticity in older animals remains unknown.

$\mathrm{NO}$ can also act as retrograde messenger to persistently increase GABA release onto dopaminergic neurons in the ventral tegmental area (Nugent et al. 2007, 2009), a brain region crucial for reward processing and drug addiction. As for eCB-LTD at inhibitory synapses, this form of inhibitory LTP is heterosynaptic as it is triggered by HFS of glutamatergic fibers. In this case, induction requires NMDAR activation, postsynaptic $\mathrm{Ca}^{2+}$ rise, NO release from the dopaminergic cell and cGMP signaling in the GABAergic terminal. How exactly cGMP persistently increases GABA release remains unknown. Interestingly, a single in vivo exposure to morphine abolishes inhibitory LTP in ventral tegmental slices 24 hours later (Nugent et al. 2007), an observation consistent with the notion that exposure to addictive drugs can alter synaptic plasticity in the brain reward pathway (Kauer and Malenka 2007). Of note, both LTP (Nugent et al. 2007) and LTD (Pan et al. 2008) of inhibitory transmission may be induced in the ventral tegmental area. Although the requirements for induction differ, both types are expressed presynaptically. Finally, an activitydependent, long-lasting increase in GABA release via NO retrograde signaling has recently been reported in the thalamus (Bright and Brickley 2008), raising the possibility that a similar form of NO-dependent LTP of GABAergic transmission may occur in other brain areas.

\section{Modulatory Role of Presynaptic Receptors}

By regulating $\mathrm{Ca}^{2+}$ influx or some metabolic step downstream of $\mathrm{Ca}^{2+}$ influx, both ionotropic and metabotropic receptors at presynaptic terminals can modulate the inducibility of presynaptic LTP/LTD. Such modulation has been reported at several synapses expressing diverse forms of presynaptic plasticity. Once again, a good example can be found at the MF-CA3 synapse where both suppression and facilitation of 


\section{P.E. Castillo}

plasticity has been reported. For example, activation of presynaptic $\mathrm{GABA}_{\mathrm{B}}$ and $\kappa$ opioid receptors by endogenously-released GABA and dynorphin, respectively, increases the induction threshold for MF-LTP (Weisskopf et al. 1993; Vogt and Nicoll 1999). In addition, presumably by activating presynaptic A1 receptors, adenosine can also depress MF-LTP induction (Alzheimer et al. 1991; see also Moore et al. 2003). Activation of presynaptic type II mGluRs by synaptically-released glutamate does not seem to regulate MF-LTP induction (Vogt and Nicoll 1999) but can depotentiate MF-LTP immediately after induction (Tzounopoulos et al. 1998; Chen et al. 2001). In contrast to these suppressive effects, several studies have shown that induction of MF-LTP can be facilitated by presynaptic kainate receptors (KARs) (for a recent review, see Contractor et al. 2011). How exactly presynaptic KARs facilitate MF-LTP remains to be elucidated.

Input-Specificity and Associativity in Presynaptic LTP and LTD

Like postsynaptic LTP/LTD, presynaptic LTP/ LTD shows input-specificity and associativity, two properties making activity-dependent synaptic plasticity a good cellular model of learning. In cases requiring a retrograde messenger, the signal may diffuse and target unrelated synapses, thereby compromising input-specificity and degrading information processing. However, this theoretical possibility has not been supported experimentally. One way to ensure input-specificity is by combining retrograde signaling with presynaptic activity. This dual requirement has been shown for eCB-LTD in visual cortex (Sjöstrom et al. 2003), dorsal striatum (Singla et al. 2007), and hippocampus (Heifets et al. 2008). Similar requirements are observed for heterosynaptic associative LTP at cortico-lateral amygdala synapses, except that in this case, the signal is glutamate arising from neighboring thalamic terminals (Humeau et al. 2003). An additional mechanism underlying input-specificity can be found in cerebellar stellate cell neurons in which functional dendritic compartments preclude calcium diffu- sion along dendrites, thereby imposing spatial constrains to the synaptically-driven production of eCBs that mediate LTD at parallel fiber to stellate cell neurons synapses (Soler-Llavina and Sabatini 2006).

Associativity has also been observed at the level of the retrograde signal production in which two coincident signals are required (Bender et al. 2006; Nevian and Sakmann 2006). PLC is likely the coincident detector, integrating glutamate release via group I mGluR activation and activity-driven postsynaptic $\mathrm{Ca}^{2+}$ rise (Hashimotodani et al. 2007). Endogenous muscarinic acetylcholine receptor activation also acts as an associative signal for eCB-LTD induction in the dorsal cochlear nucleus (Zhao and Tzounopoulos 2011). These few examples illustrate how associativity is not an exclusive property of postsynaptic LTP/LTD.

\section{EXPRESSION MECHANISMS}

What changes take place at the presynaptic terminal to account for the long-lasting increase or decrease in transmitter release associated with presynaptic forms of LTP or LTD? Intensive work in this area has shown that answering this question is much harder than originally thought. An important constraint in presynaptic plasticity studies is the relatively small size of most typical presynaptic terminals in the CNS, making their accessibility for biochemical/ molecular manipulations, and both long-term live imaging and electrophysiological recordings extremely difficult. Transmitter release is a particularly complex phenomenon that involves several steps and molecular players (Südhof 2004; Pang and Sudhof 2010), allowing for multiple points of regulation (Atwood and Karunanithi 2002; Catterall and Few 2008; de Jong and Verhage 2009). Changes in transmitter release at central synapses can occur as a result of modifications in the probability of release $(\mathrm{Pr})$ and the number of functional release sites. In turn, $\operatorname{Pr}$ is determined by several factors; including the amount of $\mathrm{Ca}^{2+}$ influx through presynaptic VGCCs, the distance between these channels and the $\mathrm{Ca}^{2+}$ sensor for vesicle release, presynaptic $\mathrm{Ca}^{2+}$ dynamics, functional state, 
number and precise localization of synaptic vesicles. Transmitter release can occur in a univesicular or multivesicular manner, and the magnitude of the multivesicular release component can be altered during presynaptic plasticity (Bender et al. 2009). In addition to changes in Pr, "presynaptic unsilencing" (Voronin 1994; Kerchner and Nicoll 2008) could also contribute to plasticity. Indeed, studies using dentate granule cell autapses (Tong et al. 1996) and optical imaging of postsynaptic $\mathrm{Ca}^{2+}$ transients in slice culture (Reid et al. 2004) have shown that recruitment of new release sites could participate in MF-LTP. While in theory any of these mechanisms could be involved in presynaptic forms LTP and LTD, most evidence points to two key points of regulation - presynaptic action potential-induced $\mathrm{Ca}^{2+}$ influx and the downstream release machinery (Fig. 2).

\section{Changes in Presynaptic Calcium}

$\mathrm{Ca}^{2+}$ ions play a crucial role in neurotransmission. $\mathrm{Ca}^{2+}$ influx via VGCCs triggers neurotransmitter release, and multiple mechanisms can regulate presynaptic VGCCs function (Catterall and Few 2008; Neher and Sakaba 2008). There is evidence that some forms of presynaptic LTP/LTD involve enduring changes in presynaptic $\mathrm{Ca}^{2+}$ influx. The best example can be found in the hippocampal mGluR7-dependent LTD at MF synapses on s. lucidum interneuron (MF-SLIN LTD, see above). Using two-photon
$\mathrm{Ca}^{2+}$ imaging from anatomically defined MF terminals and selective VGCC blockers, this form of LTD has been shown to be associated with a long-lasting depression of the presynaptic $\mathrm{Ca}^{2+}$ transient, which arises through a preferential depression of P/Q-type VGCCs and is blocked by an mGluR7 antagonist (Pelkey et al. 2006). How exactly mGluR7 activation produces irreversible depression of P/Q-type VGCCs remains unknown but it could involve PKC-dependent modulation of these channels (Perroy et al. 2000; Pelkey et al. 2005). A similar mechanism of expression mediated by presynaptic P/Q-type VGCCs has been reported in the nucleus accumbens. In this structure, two forms of presynaptic LTD at excitatory cortical inputs coexist (Table 1); one is induced by HFS and requires activation of presynaptic mGluR2/3 (Robbe et al. 2002a), whereas the other is triggered by moderate repetitive stimulation and requires activation of presynaptic CB1R (Robbe et al. 2002b; Mato et al. 2008). Both forms of LTD depend on cAMP/PKA signaling consistent with the fact that $\mathrm{mGluR} 2 / 3$ and CB1R are $G_{i} / o$ protein-coupled receptors. Remarkably, blockade of P/Q-type, but not of L- or N-type, VGCCs occludes both forms of LTD (Robbe et al. 2002a; Mato et al. 2008), which also mutually occlude (Mato et al. 2005), suggesting that mGluR2/3-LTD and eCB-LTD share a common mechanism.

Two recent studies suggest that long-lasting changes in presynaptic $\mathrm{Ca}^{2+}$ influx also underlie
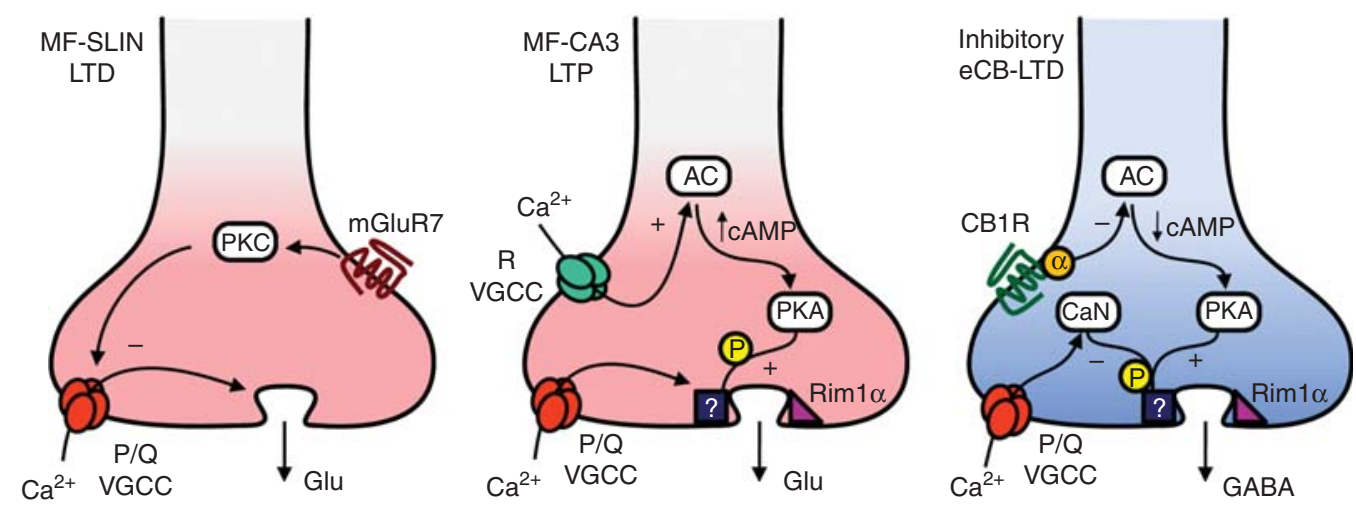

Figure 2. Expression mechanisms of presynaptic LTP and LTD: three prototypical examples (see text). 
P.E. Castillo

presynaptic forms of LTP, but in this case L-type and N-type VGCCs seem to be involved. Indeed, using electrophysiological recordings and two-photon imaging of FM1-43 dye uptake and release at presynaptic terminals, one study showed that LTP at perforant path synapses in CA1 is associated with an enduring increase in the contribution of N-type VGCCs to transmitter release (Ahmed and Siegelbaum 2009). In contrast, the other study reported that presynaptic expression of associative LTP in lateral amygdala is caused by a persistent increase in L-type VGCC-mediated glutamate release (Fourcaudot et al. 2009), which is an intriguing observation given that presynaptic $\mathrm{Ca}^{2+}$ influx at most synapses is mainly mediated by N-type and P/Q-type VGCCs, but not L-type VGCCs. Future studies are required to determine the role of VGCCs in the expression of other forms or presynaptic LTP.

A potential role of presynaptic $\mathrm{Ca}^{2+}$ influx in presynaptic LTP was also examined in the hippocampus at the MF-CA3 synapse. Using direct imaging of the action potential-dependent presynaptic $\mathrm{Ca}^{2+}$ transient in MF boutons, several studies have consistently shown that no change in presynaptic $\mathrm{Ca}^{2+}$ occurs following MF-LTP (Regehr and Tank 1991; Kamiya et al. 2002; Reid et al. 2004). Similarly, no changes in $\mathrm{Ca}^{2+}$ transients were observed in the cerebellum following cAMP-mediated potentiation of parallel fiber to Purkinje cell synaptic transmission (Chen and Regehr 1997), a chemical form of plasticity that mimics synaptically-induced PF-LTP (Salin et al. 1996a). Together, these studies show that the long-lasting enhancement of transmitter release, at least at these synapses, must occur downstream from $\mathrm{Ca}^{2+}$ entry.

Finally, indirect changes in $\mathrm{Ca}^{2+}$ entry through VGCCs can occur as a result of modifications in the presynaptic action potential waveform. Although modulations in the excitability of the presynaptic terminal as a mechanism of synaptic plasticity have been well documented in invertebrates (for a recent review, see Glanzman 2010), the evidence for such a mechanism underlying presynaptic LTP or LTD in vertebrates is rather scarce.

\section{Changes in the Release Machinery}

The other major mechanism for regulating neurotransmitter release is via modulation of the molecular machinery responsible for synaptic vesicle exocytosis. Given the large number of proteins involved in this complex process, several candidate proteins could potentially mediate long-term synaptic plasticity, and some of them have been directly tested mainly using gene knockout approaches. One way to modulate function of these proteins is by protein phosphorylation (Leenders and Sheng 2005; de Jong and Verhage 2009). Because of the key role of cAMP/PKA signaling in multiple forms of presynaptic LTP and LTD (see above), most attention has been directed to presynaptic proteins known to be substrates for PKA (Seino and Shibasaki 2005). Among these proteins, synapsins (Spillane et al. 1995), rabphilin (Schlüter et al. 1999) and tomosyn (Sakisaka et al. 2008) have been shown to play no role in presynaptic MF-LTP. In contrast, the active zone protein RIM1 $\alpha$ has emerged as a key player not only in MF-LTP but also several others forms of presynaptic plasticity (Kaeser and Sudhof 2005). Interestingly, deletion of RIM1 $\alpha$ is associated with significant cognitive deficits (Powell et al. 2004). RIM $1 \alpha$ is a large multidomain protein that forms a scaffold at the presynaptic active zone and interacts with multiple presynaptic proteins. As a result, RIM $1 \alpha$ is in a strategic position to modulate transmitter release (Koushika et al. 2001; Schoch et al. 2002). Indeed, RIM1 $\alpha$ has been shown to be necessary for several cAMP/PKA-dependent forms of presynaptic plasticity including, MF-LTP (Castillo et al. 2002), cerebellar PF-LTP (Castillo et al. 2002), MF-SLIN LTP or de-depression (Pelkey et al. 2008), associative LTP in lateral amygdala (Fourcaudot et al. 2008), late LTP at Sch-CA1 synapses (Huang et al. 2005), GABAergic LTP at stellate cells in cerebellum (Lachamp et al. 2009), and inhibitory eCB-LTD in the hippocampus and amygdala (Chevaleyre et al. 2007). In addition, RIM $1 \alpha$ is a putative effector for the synaptic vesicle protein Rab3A, a protein essential for MF-LTP (Castillo et al. 1997), MFLTD (Tzounopoulos et al. 1998), and late-LTP 
in CA1 (Huang et al. 2005). The mechanism emerging from these studies is that increases of PKA activity and RIM1 $\alpha$ phosphorylation leads to LTP, whereas a reduction of PKA activity, in conjunction with phosphatase activity, dephosphorylates RIM1 $\alpha$, which results in LTD. However, recent studies have challenged this simplistic model by demonstrating that mutation of serine- 413 , the RIM1 $\alpha$ phosphorylation site by PKA that has reported to be necessary for presynaptic LTP in parallel fiber synapses formed in vitro by cultured cerebellar neurons (Lonart et al. 2003), had no effect on MF-LTP, PF-LTP and eCB-LTD at inhibitory synapses (Kaeser et al. 2008; Yang and Calakos 2010). This observation is consistent with the fact that the presynaptic enhancement of synaptic transmission following transient activation of adenylyl cyclase is unaltered in knockout mice lacking Rab3A or Riml $\alpha$ (Castillo et al. 1997, 2002). Together, these findings argue that, although the RIM1 $\alpha$ complex is essential for presynaptic long-term plasticity, PKA regulates this type of plasticity by a mechanism distinct from RIM1 $\alpha$ phosphorylation at serine 413. In fact, PKA-dependent modulation of transmitter release can occur as a result of the phosphorylation/ dephosphorylation of several other presynaptic proteins involved in exocytosis (Seino and Shibasaki 2005; de Jong and Verhage 2009). Future studies are necessary to identify the nature of such a presynaptic protein(s) in PKA-dependent and RIM1 $\alpha$-dependent forms of plasticity. Remarkably, not all forms of presynaptic LTP/LTD require cAMP/ PKA signaling, and as a result, the number of candidate presynaptic proteins putatively involved in synaptic plasticity may be larger than expected.

\section{CONCLUSIONS, CHALLENGES, AND FUTURE DIRECTIONS}

More than two decades of research unequivocally showed that long-term presynaptic plasticity at excitatory and inhibitory synapses is widely used throughout the brain. Although some learning rules for presynaptic LTP and LTD are now understood, many questions re- main to be elucidated. Chief among them is the precise molecular pathways underlying presynaptic plasticity. Although some key "players" have been identified, there are several loose ends. Presynaptic and postsynaptic LTP/LTD can coexist, and often times their induction differs, but in some cases overlap. It is unclear how these different forms of plasticity interact and how they contribute to information processing.

The retrograde signal involved in the induction of multiple forms of presynaptic LTP/ LTD needs to be identified. Although most studies focused on presynaptic LTP/LTD induction and expression, much less is known about the maintenance and reversibility. Moreover, protein synthesis seems to be required for presynaptic plasticity at the MF-CA3 synapse (Huang et al. 1994; Calixto et al. 2003; Barnes et al. 2010) and in the dorsal striatum (Yin et al. 2006), and there is evidence that protein synthesis can occur in the presynaptic compartment (Giuditta et al. 2002; Yin et al. 2006; Barnes et al. 2010). The role of the newly synthesized proteins and their potential contribution to putative structural changes in presynaptic plasticity remains largely unexplored. Other future research areas include the potential contribution of glia, interactions between various modulatory systems and metaplasticity of presynaptic LTP/LTD.

Perhaps the most difficult challenge ahead is to understand how presynaptic long-term plasticity contributes to behavior. Accumulating evidence strongly suggest that presynaptic forms of plasticity can underlie some forms of learning. A good example can be found in the amygdala where presynaptic LTP and LTD are known to contribute to fear memory (Maren 2005; Sigurdsson et al. 2007; Sah et al. 2008; Pape and Pare 2010). The link between plasticity and behavior in other brain areas is assumed and more difficult to show. Synaptic plasticity is typically studied in brain slices, often times using relatively nonphysiological induction protocols and recording conditions. Although an extremely powerful experimental model to address mechanistic questions, the concepts developed from slice physiology need to be tested in intact animal preparations to fully understand 


\section{P.E. Castillo}

the contribution of presynaptic forms of plasticity to behavior.

\section{ACKNOWLEDGMENTS}

Special thanks to Thomas Younts and Sachin Makani for critical reading of the manuscript. The author apologizes to all the investigators whose work could not be cited owing to space limitations. P.E.C is supported by the National Institutes of Health/National Institute on Drug Abuse and National Institute of Mental Health grants, and the Irma T. Hirschl Career Scientist Award.

\section{REFERENCES}

Ahmed MS, Siegelbaum SA. 2009. Recruitment of N-Type $\mathrm{Ca}^{2+}$ channels during LTP enhances low release efficacy of hippocampal CA1 perforant path synapses. Neuron 63: $372-385$.

Alger BE. 2002. Retrograde signaling in the regulation of synaptic transmission: Focus on endocannabinoids. Prog Neurobiol 68: 247-286.

Alle H, Jonas P, Geiger JR. 2001. PTP and LTP at a hippocampal mossy fiber-interneuron synapse. Proc Natl Acad Sci 98: $14708-14713$.

Alzheimer C, Rohrenbeck J, ten Bruggencate G. 1991. Adenosine depresses induction of LTP at the mossy fiberCA3 synapse in vitro. Brain Res 543: 163-165.

Armstrong JN, Saganich MJ, Xu NJ, Henkemeyer M, Heinemann SF, Contractor A. 2006. B-ephrin reverse signaling is required for NMDA-independent long-term potentiation of mossy fibers in the hippocampus. J Neurosci 26: 3474-3481.

Atwood HL, Karunanithi S. 2002. Diversification of synaptic strength: Presynaptic elements. Nat Rev Neurosci 3: 497516.

Azad SC, Monory K, Marsicano G, Cravatt BF, Lutz B, Zieglgansberger W, Rammes G. 2004. Circuitry for associative plasticity in the amygdala involves endocannabinoid signaling. J Neurosci 24: 9953-9961.

Barnes SJ, Opitz T, Merkens M, Kelly T, von der Brelie C, Krueppel R, Beck H. 2010. Stable mossy fiber long-term potentiation requires calcium influx at the granule cell soma, protein synthesis, and microtubule-dependent axonal transport. J Neurosci 30: 12996-13004.

Bayazitov IT, Richardson RJ, Fricke RG, Zakharenko SS. 2007. Slow presynaptic and fast postsynaptic components of compound long-term potentiation. J Neurosci 27: 11510-11521.

Behr J, Wozny C, Fidzinski P, Schmitz D. 2009. Synaptic plasticity in the subiculum. Prog Neurobiol 89: 334-342.

Bender VA, Bender KJ, Brasier DJ, Feldman DE. 2006. Two coincidence detectors for spike timing-dependent plasticity in somatosensory cortex. J Neurosci 26: 41664177.
Bender VA, Pugh JR, Jahr CE. 2009. Presynaptically expressed long-term potentiation increases multivesicular release at parallel fiber synapses. J Neurosci 29: 1097410978.

Blum R, Konnerth A. 2005. Neurotrophin-mediated rapid signaling in the central nervous system: Mechanisms and functions. Physiology (Bethesda) 20: 70-78.

Bolshakov VY, Siegelbaum SA. 1994. Postsynaptic induction and presynaptic expression of hippocampal long-term depression. Science 264: 1148-1152.

Breustedt J, Vogt KE, Miller RJ, Nicoll RA, Schmitz D. 2003. $\alpha 1 \mathrm{E}$-containing $\mathrm{Ca}^{2+}$ channels are involved in synaptic plasticity. Proc Natl Acad Sci 100: 12450-12455.

Bright DP, Brickley SG. 2008. Acting locally but sensing globally: Impact of GABAergic synaptic plasticity on phasic and tonic inhibition in the thalamus. J Physiol 586: 5091-5099.

Calixto E, Thiels E, Klann E, Barrionuevo G. 2003. Early maintenance of hippocampal mossy fiber-long-term potentiation depends on protein and RNA synthesis and presynaptic granule cell integrity. $J$ Neurosci 23: 4842-4849.

Caporale N, Dan Y. 2008. Spike timing-dependent plasticity: A Hebbian learning rule. Annu Rev Neurosci 31: 25-46.

Castillo PE, Weisskopf MG, Nicoll RA. 1994. The role of $\mathrm{Ca}^{2+}$ channels in hippocampal mossy fiber synaptic transmission and long-term potentiation. Neuron 12: 261269.

Castillo PE, Janz R, Sudhof TC, Tzounopoulos T, Malenka RC, Nicoll RA. 1997. Rab3A is essential for mossy fibre long-term potentiation in the hippocampus. Nature 388: $590-593$.

Castillo PE, Schoch S, Schmitz F, Sudhof TC, Malenka RC. 2002. RIM1 $\alpha$ is required for presynaptic long-term potentiation. Nature 415: 327-330.

Castillo PE, Chiu CQ, Carroll RC. 2011. Long-term plasticity at inhibitory synapses. Curr Opin Neurobiol 21: 328-338.

Castro-Alamancos MA, Calcagnotto ME. 1999. Presynaptic long-term potentiation in corticothalamic synapses. J Neurosci 19: 9090-9097.

Catterall WA, Few AP. 2008. Calcium channel regulation and presynaptic plasticity. Neuron 59: 882-901.

Chen C, Regehr WG. 1997. The mechanism of cAMP-mediated enhancement at a cerebellar synapse. J Neurosci 17: 8687-8694.

Chen YL, Huang CC, Hsu KS. 2001. Time-dependent reversal of long-term potentiation by low-frequency stimulation at the hippocampal mossy fiber-CA3 synapses. J Neurosci 21: 3705-3714.

Chen HX, Jiang M, Akakin D, Roper SN. 2009. Long-term potentiation of excitatory synapses on neocortical somatostatin-expressing interneurons. J Neurophysiol 102: 3251-3259.

Chevaleyre V, Castillo PE. 2003. Heterosynaptic LTD of hippocampal GABAergic synapses: A novel role of endocannabinoids in regulating excitability. Neuron 38: 461-472.

Chevaleyre V, Castillo PE. 2004. Endocannabinoid-mediated metaplasticity in the hippocampus. Neuron 43: 871-881.

Chevaleyre V, Takahashi KA, Castillo PE. 2006. Endocannabinoid-mediated synaptic plasticity in the CNS. Annu Rev Neurosci 29: 37-76. 
Chevaleyre V, Heifets BD, Kaeser PS, Sudhof TC, Castillo PE 2007. Endocannabinoid-mediated long-term plasticity requires cAMP/PKA signaling and RIM1 $\alpha$. Neuron 54: 801-812.

Chiu CQ, Puente N, Grandes P, Castillo PE. 2010. Dopaminergic modulation of endocannabinoid-mediated plasticity at GABAergic synapses in the prefrontal cortex. J Neurosci 30: 7236-7248.

Contractor A, Rogers C, Maron C, Henkemeyer M, Swanson GT, Heinemann SF. 2002. Trans-synaptic Eph receptorephrin signaling in hippocampal mossy fiber LTP. Science 296: $1864-1869$.

Contractor A, Mulle C, Swanson GT. 2011. Kainate receptors coming of age: Milestones of two decades of research. Trends Neurosci 34: 154-163.

Corlew R, Wang Y, Ghermazien H, Erisir A, Philpot BD. 2007. Developmental switch in the contribution of presynaptic and postsynaptic NMDA receptors to long-term depression. J Neurosci 27: 9835-9845.

Corlew R, Brasier DJ, Feldman DE, Philpot BD. 2008. Presynaptic NMDA receptors: Newly appreciated roles in cortical synaptic function and plasticity. Neuroscientist 14: 609-625.

de Jong AP, Verhage M. 2009. Presynaptic signal transduction pathways that modulate synaptic transmission. Curr Opin Neurobiol 19: 245-253.

Dietrich D, Kirschstein T, Kukley M, Pereverzev A, von der Brelie C, Schneider T, Beck H. 2003. Functional specialization of presynaptic Cav2.3 $\mathrm{Ca}^{2+}$ channels. Neuron 39: 483-496.

Du JL, Poo MM. 2004. Rapid BDNF-induced retrograde synaptic modification in a developing retinotectal system. Nature 429: 878-883.

Duguid I, Sjostrom PJ. 2006. Novel presynaptic mechanisms for coincidence detection in synaptic plasticity. Curr Opin Neurobiol 16: 312-322.

Duguid IC, Smart TG. 2004. Retrograde activation of presynaptic NMDA receptors enhances GABA release at cerebellar interneuron-Purkinje cell synapses. Nat Neurosci 7: 525-533.

Engelman HS, MacDermott AB. 2004. Presynaptic ionotropic receptors and control of transmitter release. Nat Rev Neurosci 5: 135-145.

Feil R, Kleppisch T. 2008. NO/cGMP-dependent modulation of synaptic transmission. Handb Exp Pharmacol: 529-560.

Feinmark SJ, Begum R, Tsvetkov E, Goussakov I, Funk CD, Siegelbaum SA, Bolshakov VY. 2003. 12-lipoxygenase metabolites of arachidonic acid mediate metabotropic glutamate receptor-dependent long-term depression at hippocampal CA3-CA1 synapses. J Neurosci 23: 11427 11435 .

Fourcaudot E, Gambino F, Humeau Y, Casassus G, Shaban H, Poulain B, Luthi A. 2008. cAMP/PKA signaling and RIM1 $\alpha$ mediate presynaptic LTP in the lateral amygdala. Proc Natl Acad Sci 105: 15130-15135.

Fourcaudot E, Gambino F, Casassus G, Poulain B, Humeau Y, Luthi A. 2009. L-type voltage-dependent $\mathrm{Ca}^{2+}$ channels mediate expression of presynaptic LTP in amygdala. Nat Neurosci 12: 1093-1095.
Futai K, Kim MJ, Hashikawa T, Scheiffele P, Sheng M, Hayashi Y. 2007. Retrograde modulation of presynaptic release probability through signaling mediated by PSD95-neuroligin. Nat Neurosci 10: 186-195.

Galvan EJ, Calixto E, Barrionuevo G. 2008. Bidirectional Hebbian plasticity at hippocampal mossy fiber synapses on CA3 interneurons. J Neurosci 28: 14042-14055.

Galvan EJ, Cosgrove KE, Mauna JC, Card JP, Thiels E, Meriney SD, Barrionuevo G. 2010. Critical involvement of postsynaptic protein kinase activation in long-term potentiation at hippocampal mossy fiber synapses on CA3 interneurons. J Neurosci 30: 2844-2855.

Galvan EJ, Cosgrove KE, Barrionuevo G. 2011. Multiple forms of long-term synaptic plasticity at hippocampal mossy fiber synapses on interneurons. Neuropharmacology 60: 740-747.

Gerdeman GL, Ronesi J, Lovinger DM. 2002. Postsynaptic endocannabinoid release is critical to long-term depression in the striatum. Nat Neurosci 5: 446-451.

Gibson HE, Edwards JG, Page RS, Van Hook MJ, Kauer JA. 2008. TRPV1 channels mediate long-term depression at synapses on hippocampal interneurons. Neuron 57: 746-759.

Giuditta A, Kaplan BB, van Minnen J, Alvarez J, Koenig E. 2002. Axonal and presynaptic protein synthesis: New insights into the biology of the neuron. Trends Neurosci 25: 400-404.

Glanzman DL. 2010. Common mechanisms of synaptic plasticity in vertebrates and invertebrates. Curr Biol 20: R31-R36.

Gottmann K. 2008. Transsynaptic modulation of the synaptic vesicle cycle by cell-adhesion molecules. J Neurosci Res 86: $223-232$.

Gubellini P, Ben-Ari Y, Gaiarsa JL. 2005. Endogenous neurotrophins are required for the induction of GABAergic long-term potentiation in the neonatal rat hippocampus. J Neurosci 25: 5796-5802.

Gundlfinger A, Breustedt J, Sullivan D, Schmitz D. 2010. Natural spike trains trigger short- and long-lasting dynamics at hippocampal mossy fiber synapses in rodents. PLoS One 5: e9961.

Harris EW, Cotman CW. 1986. Long-term potentiation of guinea pig mossy fiber responses is not blocked by $\mathrm{N}$ methyl D-aspartate antagonists. Neurosci Lett 70: 132 137.

Hashimotodani Y, Ohno-Shosaku T, Kano M. 2007. $\mathrm{Ca}^{2+}$. assisted receptor-driven endocannabinoid release: Mechanisms that associate presynaptic and postsynaptic activities. Curr Opin Neurobiol 17: 360-365.

Hawkins RD, Son H, Arancio O. 1998. Nitric oxide as a retrograde messenger during long-term potentiation in hippocampus. Prog Brain Res 118: 155-172.

Heifets BD, Castillo PE. 2009. Endocannabinoid signaling and long-term synaptic plasticity. Annu Rev Physiol 71: 283-306.

Heifets BD, Chevaleyre V, Castillo PE. 2008. Interneuron activity controls endocannabinoid-mediated presynaptic plasticity through calcineurin. Proc Natl Acad Sci 105: 10250-10255. 


\section{P.E. Castillo}

Huang YY, Kandel ER. 1998. Postsynaptic induction and PKA-dependent expression of LTP in the lateral amygdala. Neuron 21: 169-178.

Huang YY, Li XC, Kandel ER. 1994. cAMP contributes to mossy fiber LTP by initiating both a covalently mediated early phase and macromolecular synthesis-dependent late phase. Cell 79: 69-79.

Huang YY, Zakharenko SS, Schoch S, Kaeser PS, Janz R, Sudhof TC, Siegelbaum SA, Kandel ER. 2005. Genetic evidence for a protein-kinase-A-mediated presynaptic component in NMDA-receptor-dependent forms of long-term synaptic potentiation. Proc Natl Acad Sci 102: $9365-9370$.

Huang Y, Yasuda H, Sarihi A, Tsumoto T. 2008. Roles of endocannabinoids in heterosynaptic long-term depression of excitatory synaptic transmission in visual cortex of young mice. J Neurosci 28: 7074-7083.

Humeau Y, Shaban H, Bissiere S, Luthi A. 2003. Presynaptic induction of heterosynaptic associative plasticity in the mammalian brain. Nature 426: 841-845.

Inagaki T, Begum T, Reza F, Horibe S, Inaba M, Yoshimura Y, Komatsu Y. 2008. Brain-derived neurotrophic factormediated retrograde signaling required for the induction of long-term potentiation at inhibitory synapses of visual cortical pyramidal neurons. Neurosci Res 61: 192-200.

Jaffe D, Johnston D. 1990. Induction of long-term potentiation at hippocampal mossy-fiber synapses follows a Hebbian rule. J Neurophysiol 64: 948-960.

Jiang B, Huang S, de Pasquale R, Millman D, Song L, Lee HK, Tsumoto T, Kirkwood A. 2010. The maturation of GABAergic transmission in visual cortex requires endocannabinoid-mediated LTD of inhibitory inputs during a critical period. Neuron 66: 248-259.

Kaeser PS, Sudhof TC. 2005. RIM function in short- and longterm synaptic plasticity. Biochem Soc Trans 33: 1345-1349.

Kaeser PS, Kwon HB, Blundell J, Chevaleyre V, Morishita W, Malenka RC, Powell CM, Castillo PE, Sudhof TC. 2008. RIM1 $\alpha$ phosphorylation at serine- 413 by protein kinase $\mathrm{A}$ is not required for presynaptic long-term plasticity or learning. Proc Natl Acad Sci 105: 14680-14685.

Kamiya H, Umeda K, Ozawa S, Manabe T. 2002. Presynaptic $\mathrm{Ca}^{2+}$ entry is unchanged during hippocampal mossy fiber long-term potentiation. J Neurosci 22: 10524-10528.

Kano M, Ohno-Shosaku T, Hashimotodani Y, Uchigashima M, Watanabe M. 2009. Endocannabinoid-mediated control of synaptic transmission. Physiol Rev 89: 309-380.

Kapur A, Yeckel MF, Gray R, Johnston D. 1998. L-Type calcium channels are required for one form of hippocampal mossy fiber LTP. J Neurophysiol 79: 2181-2190.

Kato K, Clark GD, Bazan NG, Zorumski CF. 1994. Plateletactivating factor as a potential retrograde messenger in CA1 hippocampal long-term potentiation. Nature 367: 175-179.

Kauer JA, Malenka RC. 2007. Synaptic plasticity and addiction. Nat Rev Neurosci 8: 844-858.

Kerchner GA, Nicoll RA. 2008. Silent synapses and the emergence of a postsynaptic mechanism for LTP. Nat Rev Neurosci 9: 813-825.

Kobayashi K, Manabe T, Takahashi T. 1996. Presynaptic long-term depression at the hippocampal mossy fiberCA3 synapse. Science 273: 648-650.
Kobayashi K, Manabe T, Takahashi T. 1999. Calcium-dependent mechanisms involved in presynaptic long-term depression at the hippocampal mossy fibre-CA3 synapse. Eur J Neurosci 11: 1633-1638.

Kokaia M. 2000. Long-term potentiation of single subicular neurons in mice. Hippocampus 10: 684-692.

Koushika SP, Richmond JE, Hadwiger G, Weimer RM, Jorgensen EM, Nonet ML. 2001. A post-docking role for active zone protein Rim. Nat Neurosci 4: 997-1005.

Kreitzer AC, Malenka RC. 2007. Endocannabinoid-mediated rescue of striatal LTD and motor deficits in Parkinson's disease models. Nature 445: 643-647.

Kuczewski N, Porcher C, Gaiarsa JL. 2010. Activity-dependent dendritic secretion of brain-derived neurotrophic factor modulates synaptic plasticity. Eur J Neurosci 32: 1239-1244.

Kullmann DM, Lamsa KP. 2011. LTP and LTD in cortical GABAergic interneurons: Emerging rules and roles. Neuropharmacology 60: 712-719.

Lachamp PM, Liu Y, Liu SJ. 2009. Glutamatergic modulation of cerebellar interneuron activity is mediated by an enhancement of GABA release and requires protein kinase A/RIM1 $\alpha$ signaling. J Neurosci 29: 381-392.

Lafourcade M, Elezgarai I, Mato S, Bakiri Y, Grandes P, Manzoni OJ. 2007. Molecular components and functions of the endocannabinoid system in mouse prefrontal cortex. PLoS One 2: e709.

Lamsa KP, Heeroma JH, Somogyi P, Rusakov DA, Kullmann DM. 2007. Anti-Hebbian long-term potentiation in the hippocampal feedback inhibitory circuit. Science 315: $1262-1266$.

Lapointe V, Morin F, Ratte S, Croce A, Conquet F, Lacaille JC. 2004. Synapse-specific mGluR1-dependent longterm potentiation in interneurones regulates mouse hippocampal inhibition. J Physiol 555: 125-135.

Larsen RS, Corlew RJ, Henson MA, Roberts AC, Mishina M, Watanabe M, Lipton SA, Nakanishi N, Perez-Otano I, Weinberg RJ, et al. 2011. NR3A-containing NMDARs promote neurotransmitter release and spike timingdependent plasticity. Nat Neurosci 14: 338-344.

Leenders AG, Sheng ZH. 2005. Modulation of neurotransmitter release by the second messenger-activated protein kinases: Implications for presynaptic plasticity. Pharmacol Ther 105: 69-84.

Lei S, McBain CJ. 2004. Two Loci of expression for longterm depression at hippocampal mossy fiber-interneuron synapses. J Neurosci 24: 2112-2121.

Lessmann V, Gottmann K, Malcangio M. 2003. Neurotrophin secretion: Current facts and future prospects. Prog Neurobiol 69: 341-374.

Lien CC, Mu Y, Vargas-Caballero M, Poo MM. 2006. Visual stimuli-induced LTD of GABAergic synapses mediated by presynaptic NMDA receptors. Nat Neurosci 9: $372-$ 380.

Linden DJ, Ahn S. 1999. Activation of presynaptic cAMPdependent protein kinase is required for induction of cerebellar long-term potentiation. J Neurosci 19: 1022110227.

Lisman J, Raghavachari S. 2006. A unified model of the presynaptic and postsynaptic changes during LTP at CA1 synapses. Sci STKE 2006: rel1. 
Liu SJ, Lachamp P. 2006. The activation of excitatory glutamate receptors evokes a long-lasting increase in the release of GABA from cerebellar stellate cells. J Neurosci 26: 9332-9339.

Liu Y, Zhang LI, Tao HW. 2007. Heterosynaptic scaling of developing GABAergic synapses: Dependence on glutamatergic input and developmental stage. J Neurosci 27: 5301-5312.

Lonart G, Schoch S, Kaeser PS, Larkin CJ, Sudhof TC, Linden DJ. 2003. Phosphorylation of RIM1 $\alpha$ by PKA triggers presynaptic long-term potentiation at cerebellar parallel fiber synapses. Cell 115: 49-60.

Lopez de Armentia M, Sah P. 2007. Bidirectional synaptic plasticity at nociceptive afferents in the rat central amygdala. J Physiol 581: 961-970.

Lu B. 2003. BDNF and activity-dependent synaptic modulation. Learn Mem 10: 86-98.

Lu JT, Li CY, Zhao JP, Poo MM, Zhang XH. 2007. Spiketiming-dependent plasticity of neocortical excitatory synapses on inhibitory interneurons depends on target cell type. J Neurosci 27: 9711-9720.

Lyon L, Borel M, Carrion M, Kew JN, Corti C, Harrison PJ, Burnet PW, Paulsen O, Rodriguez-Moreno A. 2011. Hippocampal mossy fiber LTD in Grm2/3 double knockout mice. Synapse 65: 945-954.

Lysetskiy M, Foldy C, Soltesz I. 2005. Long- and short-term plasticity at mossy fiber synapses on mossy cells in the rat dentate gyrus. Hippocampus 15: 691-696.

Maccaferri G, Toth K, McBain CJ. 1998. Target-specific expression of presynaptic mossy fiber plasticity. Science 279: $1368-1370$.

Magby JP, Bi C, Chen ZY, Lee FS, Plummer MR. 2006. Single-cell characterization of retrograde signaling by brainderived neurotrophic factor. J Neurosci 26: 13531-13536.

Maione S, Cristino L, Migliozzi AL, Georgiou AL, Starowicz K, Salt TE, Di Marzo V. 2009. TRPV1 channels control synaptic plasticity in the developing superior colliculus. J Physiol 587: 2521-2535.

Maren S. 2005. Synaptic mechanisms of associative memory in the amygdala. Neuron 47: 783-786.

Marsicano G, Wotjak CT, Azad SC, Bisogno T, Rammes G, Cascio MG, Hermann H, Tang J, Hofmann C, Zieglgansberger W, et al. 2002. The endogenous cannabinoid system controls extinction of aversive memories. Nature 418: $530-534$.

Mato S, Robbe D, Puente N, Grandes P, Manzoni OJ. 2005. Presynaptic homeostatic plasticity rescues long-term depression after chronic $\delta$ 9-tetrahydrocannabinol exposure. J Neurosci 25: 11619-11627.

Mato S, Lafourcade M, Robbe D, Bakiri Y, Manzoni OJ 2008. Role of the cyclic-AMP/PKA cascade and of P/ Q-type $\mathrm{Ca}^{2+}$ channels in endocannabinoid-mediated long-term depression in the nucleus accumbens. Neuropharmacology 54: 87-94.

McBain CJ. 2008. Differential mechanisms of transmission and plasticity at mossy fiber synapses. Prog Brain Res 169: $225-240$.

McBain CJ, Kauer JA. 2009. Presynaptic plasticity: Targeted control of inhibitory networks. Curr Opin Neurobiol 19: $254-262$.
McMahon LL, Kauer JA. 1997. Hippocampal interneurons express a novel form of synaptic plasticity. Neuron 18: 295-305.

Mellor J, Nicoll RA. 2001. Hippocampal mossy fiber LTP is independent of postsynaptic calcium. Nat Neurosci 4: $125-126$.

Mistry R, Dennis S, Frerking M, Mellor JR. 2010. Dentate gyrus granule cell firing patterns can induce mossy fiber long-term potentiation in vitro. Hippocampus 21: 1157-1168.

Moore KA, Nicoll RA, Schmitz D. 2003. Adenosine gates synaptic plasticity at hippocampal mossy fiber synapses. Proc Natl Acad Sci 100: 14397-14402.

Myoga MH, Regehr WG. 2011. Calcium microdomains near R-type calcium channels control the induction of presynaptic long-term potentiation at parallel fiber to purkinje cell synapses. J Neurosci 31: 5235-5243.

Negrete-Diaz JV, Sihra TS, Delgado-Garcia JM, RodriguezMoreno A. 2007. Kainate receptor-mediated presynaptic inhibition converges with presynaptic inhibition mediated by Group II mGluRs and long-term depression at the hippocampal mossy fiber-CA3 synapse. J Neural Transm 114: 1425-1431.

Neher E, Sakaba T. 2008. Multiple roles of calcium ions in the regulation of neurotransmitter release. Neuron 59: 861-872.

Nevian T, Sakmann B. 2006. Spine $\mathrm{Ca}^{2+}$ signaling in spike-timing-dependent plasticity. J Neurosci 26: 11001-11013.

Nicoll RA, Malenka RC. 1995. Contrasting properties of two forms of long-term potentiation in the hippocampus. Nature 377: 115-118.

Nicoll RA, Schmitz D. 2005. Synaptic plasticity at hippocampal mossy fibre synapses. Nat Rev Neurosci 6: 863-876.

Nissen W, Szabo A, Somogyi J, Somogyi P, Lamsa KP. 2010. Cell type-specific long-term plasticity at glutamatergic synapses onto hippocampal interneurons expressing either parvalbumin or CB1 cannabinoid receptor. J Neurosci 30: 1337-1347.

Nugent FS, Penick EC, Kauer JA. 2007. Opioids block longterm potentiation of inhibitory synapses. Nature 446: 1086-1090.

Nugent FS, Niehaus JL, Kauer JA. 2009. PKG and PKA signaling in LTP at GABAergic synapses. Neuropsychopharmacology 34: 1829-1842.

Oliet SH, Malenka RC, Nicoll RA. 1997. Two distinct forms of long-term depression coexist in CA1 hippocampal pyramidal cells. Neuron 18: 969-982.

Oren I, Nissen W, Kullmann DM, Somogyi P, Lamsa KP. 2009. Role of ionotropic glutamate receptors in longterm potentiation in rat hippocampal CA1 oriens-lacunosum moleculare interneurons. J Neurosci 29: 939-950.

Pan B, Hillard CJ, Liu QS. 2008. Endocannabinoid signaling mediates cocaine-induced inhibitory synaptic plasticity in midbrain dopamine neurons. J Neurosci 28: 1385-1397.

Pang ZP, Sudhof TC. 2010. Cell biology of $\mathrm{Ca}^{2+}$-triggered exocytosis. Curr Opin Cell Biol 22: 496-505.

Pape HC, Pare D. 2010. Plastic synaptic networks of the amygdala for the acquisition, expression, and extinction of conditioned fear. Physiol Rev 90: 419-463.

Parpura V, Zorec R. 2010. Gliotransmission: Exocytotic release from astrocytes. Brain Res Rev 63: 83-92. 


\section{P.E. Castillo}

Pelkey KA, Lavezzari G, Racca C, Roche KW, McBain CJ. 2005. mGluR7 is a metaplastic switch controlling bidirectional plasticity of feedforward inhibition. Neuron 46: 89-102.

Pelkey KA, Topolnik L, Lacaille JC, McBain CJ. 2006. Compartmentalized $\mathrm{Ca}^{2+}$ channel regulation at divergent mossy-fiber release sites underlies target cell-dependent plasticity. Neuron 52: 497-510.

Pelkey KA, Topolnik L, Yuan XQ, Lacaille JC, McBain CJ. 2008. State-dependent cAMP sensitivity of presynaptic function underlies metaplasticity in a hippocampal feedforward inhibitory circuit. Neuron 60: 980-987.

Perez Y, Morin F, Lacaille JC. 2001. A hebbian form of longterm potentiation dependent on mGluRla in hippocampal inhibitory interneurons. Proc Natl Acad Sci 98: 9401-9406.

Perroy J, Prezeau L, De Waard M, Shigemoto R, Bockaert J, Fagni L. 2000. Selective blockade of P/Q-type calcium channels by the metabotropic glutamate receptor type 7 involves a phospholipase $\mathrm{C}$ pathway in neurons. J Neurosci 20: 7896-7904.

Piomelli D. 2003. The molecular logic of endocannabinoid signalling. Nat Rev Neurosci 4: 873-884.

Powell CM, Schoch S, Monteggia L, Barrot M, Matos MF, Feldmann N, Sudhof TC, Nestler EJ. 2004. The presynaptic active zone protein RIM1 $\alpha$ is critical for normal learning and memory. Neuron 42: 143-153.

Qiu DL, Knopfel T. 2009. Presynaptically expressed longterm depression at cerebellar parallel fiber synapses. Pflugers Arch 457: 865-875.

Rancillac A, Crepel F. 2004. Synapses between parallel fibres and stellate cells express long-term changes in synaptic efficacy in rat cerebellum. J Physiol 554: 707-720.

Regehr WG, Tank DW. 1991. The maintenance of LTP at hippocampal mossy fiber synapses is independent of sustained presynaptic calcium. Neuron 7: 451-459.

Regehr WG, Carey MR, Best AR. 2009. Activity-dependent regulation of synapses by retrograde messengers. Neuron 63: $154-170$.

Reid CA, Dixon DB, Takahashi M, Bliss TV, Fine A. 2004. Optical quantal analysis indicates that long-term potentiation at single hippocampal mossy fiber synapses is expressed through increased release probability, recruitment of new release sites, and activation of silent synapses. J Neurosci 24: 3618-3626.

Robbe D, Alonso G, Chaumont S, Bockaert J, Manzoni OJ. 2002a. Role of $\mathrm{p} / \mathrm{q}-\mathrm{Ca}^{2+}$ channels in metabotropic glutamate receptor $2 / 3$-dependent presynaptic long-term depression at nucleus accumbens synapses. J Neurosci 22: 4346-4356.

Robbe D, Kopf M, Remaury A, Bockaert J, Manzoni OJ. 2002b. Endogenous cannabinoids mediate long-term synaptic depression in the nucleus accumbens. Proc Natl Acad Sci 99: 8384-8388.

Rodriguez-Moreno A, Paulsen O. 2008. Spike timingdependent long-term depression requires presynaptic NMDA receptors. Nat Neurosci 11: 744-745.

Rodriguez-Moreno A, Banerjee A, Paulsen O. 2010. Presynaptic NMDA receptors and spike timing-dependent depression at cortical synapses. Front Synaptic Neurosci 2: 18.
Ronesi J, Gerdeman GL, Lovinger DM. 2004. Disruption of endocannabinoid release and striatal long-term depression by postsynaptic blockade of endocannabinoid membrane transport. J Neurosci 24: 1673-1679.

Sah P, Westbrook RF, Luthi A. 2008. Fear conditioning and long-term potentiation in the amygdala: What really is the connection? Ann NY Acad Sci 1129: 88-95.

Sakisaka T, Yamamoto Y, Mochida S, Nakamura M, Nishikawa K, Ishizaki H, Okamoto-Tanaka M, Miyoshi J, Fujiyoshi Y, Manabe T, et al. 2008. Dual inhibition of SNARE complex formation by tomosyn ensures controlled neurotransmitter release. J Cell Biol 183: 323-337.

Sakurai M. 1987. Synaptic modification of parallel fibrePurkinje cell transmission in in vitro guinea-pig cerebellar slices. J Physiol 394: 463-480.

Salin PA, Malenka RC, Nicoll RA. 1996a. Cyclic AMP mediates a presynaptic form of LTP at cerebellar parallel fiber synapses. Neuron 16: 797-803.

Salin PA, Scanziani M, Malenka RC, Nicoll RA. 1996b. Distinct short-term plasticity at two excitatory synapses in the hippocampus. Proc Natl Acad Sci 93: 13304-13309.

Samson RD, Pare D. 2005. Activity-dependent synaptic plasticity in the central nucleus of the amygdala. J Neurosci 25: 1847-1855.

Sarihi A, Jiang B, Komaki A, Sohya K, Yanagawa Y, Tsumoto T. 2008. Metabotropic glutamate receptor type 5-dependent long-term potentiation of excitatory synapses on fast-spiking GABAergic neurons in mouse visual cortex. J Neurosci 28: 1224-1235.

Schlüter OM, Schnell E, Verhage M, Tzonopoulos T, Nicoll RA, Janz R, Malenka RC, Geppert M, Südhof TC. 1999. Rabphilin knock-out mice reveal that rabphilin is not required for rab3 function in regulating neurotransmitter release. J Neurosci 19: 5834-5846.

Schoch S, Castillo PE, Jo T, Mukherjee K, Geppert M, Wang Y, Schmitz F, Malenka RC, Sudhof TC. 2002. RIM1 $\alpha$ forms a protein scaffold for regulating neurotransmitter release at the active zone. Nature 415: 321-326.

Seino S, Shibasaki T. 2005. PKA-dependent and PKA-independent pathways for cAMP-regulated exocytosis. Physiol Rev 85: 1303-1342.

Shen W, Flajolet M, Greengard P, Surmeier DJ. 2008. Dichotomous dopaminergic control of striatal synaptic plasticity. Science 321: 848-851.

Shibuki K, Okada D. 1992. Cerebellar long-term potentiation under suppressed postsynaptic $\mathrm{Ca}^{2+}$ activity. Neuroreport 3: 231-234.

Shin RM, Tully K, Li Y, Cho JH, Higuchi M, Suhara T, Bolshakov VY. 2010. Hierarchical order of coexisting preand postsynaptic forms of long-term potentiation at synapses in amygdala. Proc Natl Acad Sci 107: 19073-19078.

Sigurdsson T, Doyere V, Cain CK, LeDoux JE. 2007. Long-term potentiation in the amygdala: A cellular mechanism of fear learning and memory. Neuropharmacology 52: 215-227.

Singla S, Kreitzer AC, Malenka RC. 2007. Mechanisms for synapse specificity during striatal long-term depression. J Neurosci 27: 5260-5264.

Sivakumaran S, Mohajerani MH, Cherubini E. 2009. At immature mossy-fiber-CA3 synapses, correlated presynaptic and postsynaptic activity persistently enhances 
GABA release and network excitability via BDNF and cAMP-dependent PKA. J Neurosci 29: 2637-2647.

Sjöstrom PJ, Turrigiano GG, Nelson SB. 2003. Neocortical LTD via coincident activation of presynaptic NMDA and cannabinoid receptors. Neuron 39: 641-654.

Soler-Llavina GJ, Sabatini BL. 2006. Synapse-specific plasticity and compartmentalized signaling in cerebellar stellate cells. Nat Neurosci 9: 798-806.

Son H, Hawkins RD, Martin K, Kiebler M, Huang PL, Fishman MC, Kandel ER. 1996. Long-term potentiation is reduced in mice that are doubly mutant in endothelial and neuronal nitric oxide synthase. Cell 87: 1015-1023.

Spillane DM, Rosahl TW, Sudhof TC, Malenka RC. 1995 Long-term potentiation in mice lacking synapsins. Neuropharmacology 34: 1573-1579.

Storm DR, Hansel C, Hacker B, Parent A, Linden DJ. 1998. Impaired cerebellar long-term potentiation in type I adenylyl cyclase mutant mice. Neuron 20: 1199-1210.

Südhof TC. 2004. The synaptic vesicle cycle. Annu Rev Neurosci 27: 509-547.

Tao HW, Poo M. 2001. Retrograde signaling at central synapses. Proc Natl Acad Sci 98: 11009-11015.

Tong G, Malenka RC, Nicoll RA. 1996. Long-term potentiation in cultures of single hippocampal granule cells: A presynaptic form of plasticity. Neuron 16: 1147-1157.

Topolnik L, Azzi M, Morin F, Kougioumoutzakis A, Lacaille JC. 2006. mGluR1/5 subtype-specific calcium signalling and induction of long-term potentiation in rat hippocampal oriens/alveus interneurones. J Physiol 575: 115-131.

Toth K, Suares G, Lawrence JJ, Philips-Tansey E, McBain CJ. 2000. Differential mechanisms of transmission at three types of mossy fiber synapse. J Neurosci 20: 8279-8289.

Tsvetkov E, Carlezon WA, Benes FM, Kandel ER, Bolshakov VY. 2002. Fear conditioning occludes LTP-induced presynaptic enhancement of synaptic transmission in the cortical pathway to the lateral amygdala. Neuron 34: 289-300.

Tzounopoulos T, Janz R, Sudhof TC, Nicoll RA, Malenka RC. 1998. A role for cAMP in long-term depression at hippocampal mossy fiber synapses. Neuron 21: 837-845.

Tzounopoulos T, Rubio ME, Keen JE, Trussell LO. 2007. Coactivation of pre- and postsynaptic signaling mechanisms determines cell-specific spike-timing-dependent plasticity. Neuron 54: 291-301.

Urban NN, Barrionuevo G. 1996. Induction of hebbian and non-hebbian mossy fiber long-term potentiation by distinct patterns of high-frequency stimulation. J Neurosci 16: $4293-4299$.

Villacres EC, Wong ST, Chavkin C, Storm DR. 1998. Type I adenylyl cyclase mutant mice have impaired mossy fiber long-term potentiation. J Neurosci 18: 3186-3194.

Vogt KE, Nicoll RA. 1999. Glutamate and $\gamma$-aminobutyric acid mediate a heterosynaptic depression at mossy fiber synapses in the hippocampus. Proc Natl Acad Sci 96: $1118-1122$.

Voronin LL. 1994. Quantal analysis of hippocampal longterm potentiation. Rev Neurosci 5: 141-170.

Wang H, Pineda VV, Chan GC, Wong ST, Muglia LJ, Storm DR. 2003. Type 8 adenylyl cyclase is targeted to excitatory synapses and required for mossy fiber long-term potentiation. J Neurosci 23: 9710-9718.
Weisskopf MG, Zalutsky RA, Nicoll RA. 1993. The opioid peptide dynorphin mediates heterosynaptic depression of hippocampal mossy fibre synapses and modulates long-term potentiation. Nature 362: 423-427.

Weisskopf MG, Castillo PE, Zalutsky RA, Nicoll RA. 1994. Mediation of hippocampal mossy fiber long-term potentiation by cyclic AMP. Science 265: 1878-1882.

Williams JH, Errington ML, Lynch MA, Bliss TV. 1989. Arachidonic acid induces a long-term activity-dependent enhancement of synaptic transmission in the hippocampus. Nature 341: 739-742.

Wilson RI, Kunos G, Nicoll RA. 2001. Presynaptic specificity of endocannabinoid signaling in the hippocampus. Neuron 31: 453-462.

Wostrack M, Dietrich D. 2009. Involvement of Group II mGluRs in mossy fiber LTD. Synapse 63: 1060-1068.

Wozny C, Maier N, Fidzinski P, Breustedt J, Behr J, Schmitz D. 2008a. Differential cAMP signaling at hippocampal output synapses. J Neurosci 28: 14358-14362.

Wozny C, Maier N, Schmitz D, Behr J. 2008b. Two different forms of long-term potentiation at CA1-subiculum synapses. J Physiol 586: 2725-2734.

Xiang Z, Greenwood AC, Kairiss EW, Brown TH. 1994. Quantal mechanism of long-term potentiation in hippocampal mossy-fiber synapses. J Neurophysiol 71: 2552-2556.

Yang Y, Calakos N. 2010. Acute in vivo genetic rescue demonstrates that phosphorylation of RIM1 $\alpha$ serine 413 is not required for mossy fiber long-term potentiation. J Neurosci 30: 2542-2546.

Yeckel MF, Kapur A, Johnston D. 1999. Multiple forms of LTP in hippocampal CA3 neurons use a common postsynaptic mechanism. Nat Neurosci 2: 625-633.

Yin HH, Davis MI, Ronesi JA, Lovinger DM. 2006. The role of protein synthesis in striatal long-term depression. J Neurosci 26: 11811-11820.

Yokoi M, Kobayashi K, Manabe T, Takahashi T, Sakaguchi I, Katsuura G, Shigemoto R, Ohishi H, Nomura S, Nakamura K, et al. 1996. Impairment of hippocampal mossy fiber LTD in mice lacking mGluR2. Science 273: 645-647.

Zakharenko SS, Zablow L, Siegelbaum SA. 2001. Visualization of changes in presynaptic function during long-term synaptic plasticity. Nat Neurosci 4: 711-717.

Zakharenko SS, Zablow L, Siegelbaum SA. 2002. Altered presynaptic vesicle release and cycling during mGluRdependent LTD. Neuron 35: 1099-1110.

Zalutsky RA, Nicoll RA. 1990. Comparison of two forms of long-term potentiation in single hippocampal neurons. Science 248: 1619-1624.

Zhao Y, Tzounopoulos T. 2011. Physiological activation of cholinergic inputs controls associative synaptic plasticity via modulation of endocannabinoid signaling. J Neurosci 31: $3158-3168$.

Zhuo M, Small SA, Kandel ER, Hawkins RD. 1993. Nitric oxide and carbon monoxide produce activity-dependent long-term synaptic enhancement in hippocampus. Science 260: 1946-1950.

Zhuo M, Hu Y, Schultz C, Kandel ER, Hawkins RD. 1994. Role of guanylyl cyclase and cGMP-dependent protein kinase in long-term potentiation. Nature 368: 635-639. 


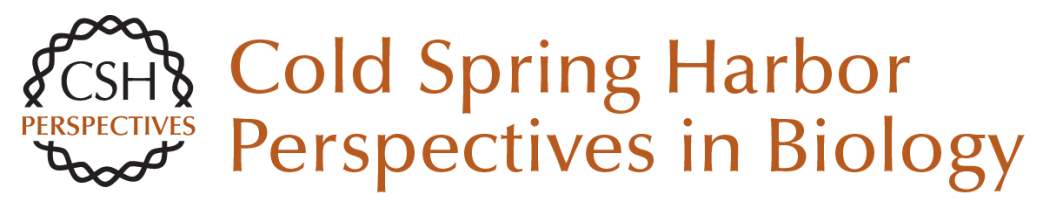

\section{Presynaptic LTP and LTD of Excitatory and Inhibitory Synapses}

Pablo E. Castillo

Cold Spring Harb Perspect Biol 2012; doi: 10.1101/cshperspect.a005728 originally published online December 6, 2011

\section{Subject Collection The Synapse}

Studying Signal Transduction in Single Dendritic Spines Ryohei Yasuda

Synaptic Vesicle Pools and Dynamics AbdulRasheed A. Alabi and Richard W. Tsien

Synapses and Memory Storage Mark Mayford, Steven A. Siegelbaum and Eric $R$. Kandel

Synapses and Alzheimer's Disease Morgan Sheng, Bernardo L. Sabatini and Thomas C. Südhof

\section{Synaptic Cell Adhesion}

Markus Missler, Thomas C. Südhof and Thomas Biederer

Synaptic Dysfunction in Neurodevelopmental Disorders Associated with Autism and Intellectual Disabilities

Huda Y. Zoghbi and Mark F. Bear

The Postsynaptic Organization of Synapses Morgan Sheng and Eunjoon Kim

Presynaptic LTP and LTD of Excitatory and Inhibitory Synapses

Pablo E. Castillo
Synaptic Vesicle Endocytosis

Yasunori Saheki and Pietro De Camilli

Short-Term Presynaptic Plasticity Wade G. Regehr

NMDA Receptor-Dependent Long-Term

Potentiation and Long-Term Depression

(LTP/LTD) Christian Lüscher and Robert C. Malenka

Ultrastructure of Synapses in the Mammalian

Brain Kristen M. Harris and Richard J. Weinberg

Calcium Signaling in Dendritic Spines Michael J. Higley and Bernardo L. Sabatini

Synaptic Neurotransmitter-Gated Receptors Trevor G. Smart and Pierre Paoletti

Synaptic Vesicle Exocytosis

Thomas C. Südhof and Josep Rizo

Vesicular and Plasma Membrane Transporters for Neurotransmitters

Randy D. Blakely and Robert H. Edwards

For additional articles in this collection, see http://cshperspectives.cshlp.org/cgi/collection/

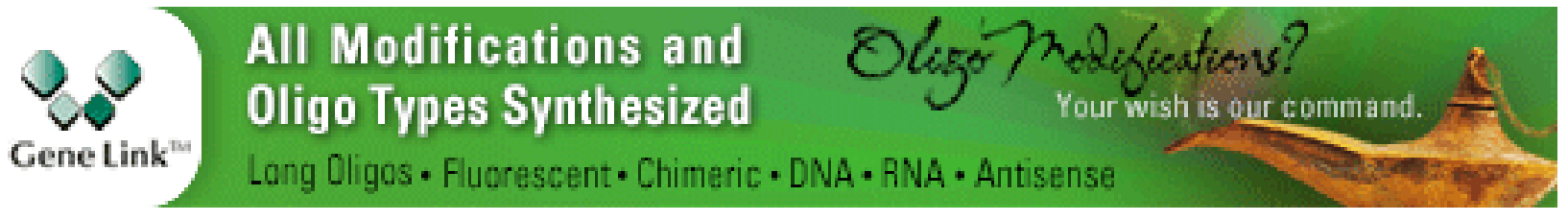

